\title{
Pharmacogenetic profiling and metabolic activity of human embryonic stem cell derived hepatocytes: focus on CYP450- mediated oxidation
}

\author{
Jenna L. Voellinger and Edward J. Kelly \\ Department of Pharmaceutics, University of Washington, Seattle, WA 98195. \\ E-mail addresses: Jenna L. Voellinger, jennav2@uw.edu; Edward J. Kelly, edkelly@uw.edu. \\ Received: March 25, 2016; Revised: May 14, 2016; Published: June 29, 2016
}

\begin{abstract}
Primary human hepatocytes are commonly used to evaluate liver drug metabolism and toxicity. Pluripotent stem cell derived hepatocytes ( $\mathrm{SCDHs}$ ) have the potential to overcome access and function-related limitations associated with primary hepatocytes. SCDHs may also provide an improved system for evaluating genotypephenotype relationships, e.g. cytochrome P450 (CYP) gene polymorphisms and their impact on drug metabolism and toxicity. However, in order for SCDHs to become routinely used in preclinical drug metabolism and toxicity screening, they must demonstrate reproducible activity of drug metabolism proteins, particularly the oxidative CYP enzymes. We characterized the differentiation status of SCDHs, with emphasis on the expression and functional capacity of drug-metabolizing enzymes, and genetically profiled the commonly used WiCell ${ }^{\circledR}$ hESC lines, focusing on CYP2D6 in our analysis. An assay of enzymatic function in SCDHs using a CYP cocktail assay designed to measure 8 different isozymes revealed only minimal activity for CYP3A, below that observed in primary hepatocytes. With regard to CYP2D6 gene copy number variation, we found the H1 line has only one gene copy, which also harbors the CYP2D6*41 splicing defect, predictive of a CYP2D6 poor/intermediate metabolizer. We identified no CYP2D6 gene duplications, indicating no representative ultra-rapid metabolizer. The $\mathrm{H} 7$ and $\mathrm{H} 14$ lines are heterozygous for the non-functional CYP2D6*4 variant resulting in a predicted intermediate metabolizer phenotype. In addition, we compared the penetrance of the CYP2D6*41 splicing defect in SCDHs and liver tissue via reverse-transcription PCR assay. We found incomplete penetrance of the CYP2D6*41 allele in liver tissue and variable penetrance in SCDHs. Based on gene expression profiling, SCDHs most closely resemble fetal hepatocytes, especially with regards to AFP, CYP3A7 and FMO1 expression. Finally, these studies indicate a low degree of genetic diversity of pharmacogenetically-relevant genes in the WiCell ${ }^{\circledR}$ hESC lines.
\end{abstract}

\section{Keywords}

Drug metabolism; ADME; in vitro

\section{Introduction}

Preclinical screening and characterization of the metabolic pathways of a new drug is a necessary part of its development and can be used to aid in predicting drug bioavailability, drug efficacy, drug-drug interactions, and drug toxicity. The main family of enzymes responsible for oxidative drug metabolism is the Cytochrome P450s (CYPs), in particular members of just three subfamilies (CYP1, CYP2 and CYP3) are primarily responsible for the metabolism of most drugs [1]. The drug-metabolizing CYPs are highly expressed in the liver, making it the primary organ to study for the metabolism, detoxification and 
elimination of drugs, and the focus of drug optimization and safety studies [2, 3]. Pharmacogenetic variability, in drug-metabolizing enzymes such as the CYPs, can influence an individual's susceptibility to drug toxicity, contributing to observed adverse drug reactions (ADRs) [4]. Drug-drug interactions are a major concern of pharmaceutical companies, particularly with respect to ADRs, a leading cause of preventable death in the United States [4]. Primary human hepatocytes are the most physiologically relevant in vitro preclinical screening system used to evaluate drug metabolism in the liver [5]. This is due to their high-expression of phase I and II drug-metabolizing enzymes, as well as phase III transporters. However, primary human hepatocytes have certain features that limit their utility in preclinical drug development, including: high donor variability, uncertain availability, short-term survival in culture, and a rapid loss of hepatic functions in culture [5-7]. Stem cell derived hepatocytes (SCDHs) may provide an alternative or complementary in vitro tool to primary human hepatocytes for evaluating drug metabolism and liver toxicity characteristics. Pluripotent stem cells have high self-renewal abilities, providing a potentially unlimited source of hepatocytes of defined genotype and phenotype $[6,8]$. In order for SCDHs to become routinely used in preclinical drug metabolism and toxicity screening, they must demonstrate reproducible activity of drug metabolism proteins, particularly the oxidative CYP enzymes. Additionally, it would be ideal if SCDHs produced metabolic activities comparable to that of primary human hepatocytes. Since SCDHs have defined genotypes, they may also provide an improved system for evaluating genotypephenotype relationships, e.g. CYP gene polymorphisms and their impact on drug metabolism and toxicity, and in particular drug-induced liver injury.

Overall, published studies demonstrate that SCDHs generated from either human embryonic stem cells (hESCS) or induced pluripotent stem cells (iPSCs), do express CYPs and other drug-metabolizing enzymes, however they seem to be at levels below those in primary human hepatocytes. In addition, the majority of studies have also reported SCDHs as still expressing $\alpha$-fetoprotein (AFP), which is highly expressed in fetal livers and not typically expressed in healthy adult livers, indicating the cells may still be in an immature state. Despite the advances made in generating SCDHs, the biggest limitation in the field to date is the inability to reproducibly and consistently generate mature hepatocytes with high levels of functional drug metabolizing enzymes. In order for SCDHs to be successfully used as an in vitro assay platform for metabolite profiling, this is something that must be overcome. This indicates there is a significant need for improvement on generating and characterizing SCDHs, particularly with regards to their metabolic capacity as it compares to primary human hepatocytes. We sought to further investigate the state of SCDHs as they compare to cryopreserved human hepatocytes, with emphasis on the expression and functional capacity of drug-metabolizing enzymes. This was done in part through gene expression profiling of pluripotency markers, hepatocyte markers, drug-metabolizing enzymes and transporters. To evaluate the functional capacity of CYP enzymes in SCDHs, metabolite formation was assessed using a CYP cocktail approach and LC-MS/MS. Additionally, to demonstrate the utility of SCDHs in pharmacogenetic predictive screening, we sought to genetically profile the commonly used WiCell ${ }^{\circledR}$ hESC lines $\mathrm{H} 1, \mathrm{H7}, \mathrm{H} 9, \mathrm{H} 13$ and $\mathrm{H} 14$ using the Affymetrix DMET ${ }^{\mathrm{TM}}$ Plus chip array. This array covers approximately 2000 polymorphisms in Absorption, Distribution, Metabolism and Excretion (ADME) relevant genes. We focused on CYP2D6 in our analysis in utilizing SCDHs for genotype-phenotype predictions, given its highly polymorphic nature and role in metabolizing about $20 \%$ of marketed drugs $[9,10]$. In terms of testing genotype-phenotype relationships for CYP2D6 in SCDHs, we assessed the penetrance of CYP2D6*41, a splicing defect which results in a CYP2D6 splice product lacking exon 6, through use of a reverse-transcription PCR assay. 


\section{Experimental}

\section{Pluripotent Stem Cells}

The hESC lines H1 (WA01), H7 (WA07), H9 (WA09), H13 (WA13), and H14 (WA14) were obtained from WiCell ${ }^{\circledast}$ Research Institute (Madison, WI, http://www.wicell.org) and propagated at the University of Washington (UW) Institute for Stem Cell and Regenerative Medicine. All studies were conducted under approval of the University of Washington Embryonic Stem Cell Research Oversight Committee.

\section{Cryopreserved Human Hepatocytes and HepaRG Cells}

Cryopreserved human hepatocyte lots HU8110 and HU8114 were purchased from Invitrogen (Carlsbad, CA) and cultured according to manufacturer's instructions. Briefly, cells were thawed in $\mathrm{CHRM}^{\circledR}$ media and plated in Williams Medium E supplemented with Hepatocyte Plating Supplement Pack from Invitrogen on 24-well plates coated with rat Collagen I. Following a 6-hour incubation period to allow for cell attachment, the media was changed to Williams Medium E supplemented with Hepatocyte Maintenance Supplement Pack from Invitrogen. Cells were maintained in this hepatocyte maintenance media for 4 days with daily fluid changes.

Cryopreserved human hepatocyte lots HUM4012 and HUM4034 were purchased from Triangle Research Labs (TRL, Research Triangle Park, NC) and cultured according to manufacturer's instructions. Briefly, cells were thawed in Animal Thawing and Plating Medium from TRL and plated in Human Hepatocyte Plating Medium from TRL supplemented with the plating supplement on 24-well plates coated with rat Collagen I. Following a 6-hour incubation period to allow for cell attachment, the media was changed to Hepatocyte Maintenance Medium supplemented with the maintenance supplement from TRL. Cells were maintained in this hepatocyte maintenance media for 3 days with daily fluid changes. In addition, plated primary human hepatocytes were kindly gifted from Dr. David Eaton's lab at the University of Washington.

Undifferentiated HepaRG cells were obtained from Biopredic International (Saint-Gregoire, France). Undifferentiated HepaRG cells were cultured in Williams Medium E (Invitrogen) supplemented with growth supplement (Biopredic) for 2 weeks with fluid changes every 2-3 days. After 2 weeks in culture, HepaRG cells were differentiated using a 50:50 mix of media supplemented with growth supplement and Williams Medium E supplemented with differentiation supplement (Biopredic). After 2 days in culture, cells were switched to $100 \%$ media with differentiation supplement. Cells were maintained in media with differentiation supplement for 2 weeks, with fluid changes every 2-3 days.

\section{Hepatocyte Differentiation}

hESCs were cultured on mouse embryonic fibroblasts (MEFs) before being transferred to Matrige ${ }^{\mathrm{TM}}$ (BD Biosciences, San Diego, CA)-coated plates using mTeSR ${ }^{\mathrm{TM}} 1$ media (Stem Cell Technologies, Vancouver, Canada). Hepatocyte differentiation was induced in three stages, as published by Hay et al [11, 12]. Briefly, differentiation was initiated at $60-70 \%$ confluence by replacing the $\mathrm{mTeSR}^{\mathrm{TM}} 1$ media with priming medium: RPMI 1640 containing 1xB27 (Invitrogen), $100 \mathrm{ng} / \mathrm{mL}$ Activin A (PeproTech, Rocky Hill, NJ), and $50 \mathrm{ng} / \mathrm{mL}$ Wnt3a (R\&D Systems, Minneapolis, MN). After 72 hours, with daily media changes, the cells were switched to differentiation medium: Knockout-DMEM containing $20 \%$ Knockout Serum Replacement, $1 \mathrm{mM}$ glutamine, $1 \%$ nonessential amino acids, $0.1 \mathrm{mM} \beta$-mercaptoethanol (Invitrogen), and $1 \%$ dimethyl sulfoxide (DMSO) (Sigma, St Louis, MO) for a further 5 days. Lastly, the cells were switched to maturation media: Hepatozyme containing $10 \mu \mathrm{M}$ hydrocortisone 21-hemisuccinate, $2 \mathrm{mM}$ glutamine, $10 \mathrm{ng} / \mathrm{mL}$ hepatocyte growth factor and $20 \mathrm{ng} / \mathrm{mL}$ oncostatin M (R\&D Systems). The media was changed every other day during maturation until the end of differentiation around day 17 . To investigate the inductive capacity 
of CYP enzymes, cells were cultured in the presence of $10 \mu \mathrm{M}$ rifampicin (Sigma), $1 \mathrm{mM}$ phenobarbital (Sigma), or $0.1 \%$ DMSO as a vehicle control for 72 hours before the end of differentiation on Day 17. Additional H9 SCDHs were a kind gift from Dr. David Hay at the University of Edinburgh.

SCDHs used for the CYP cocktail assay were differentiated using a slightly different method. Briefly, hESCs were cultured on Matrigel ${ }^{\mathrm{TM}}$ plates using $\mathrm{mTeSR}^{\mathrm{TM}} 1$ media as above. Prior to the start of differentiation, cells were passaged with $0.05 \%$ Trypsin-EDTA (Invitrogen) to single cells and $1 \times 10^{5}$ cells per well were plated on fresh Matrigel ${ }^{\mathrm{TM}}$ coated 24-well plates in $\mathrm{mTeSR}^{\mathrm{TM}} 1$ media containing $10 \mu \mathrm{M} \mathrm{Y}$ 27632 (ROCK inhibitor) (Selleck Chemicals, Houston, TX). Cells were cultured in these conditions for 24 hours and then differentiation was initiated with priming medium as described above.

\section{Fetal and adult liver tissue}

Six human fetal liver tissue samples were obtained from the Birth Defects Research Laboratory at the University of Washington, courtesy of Dr. Qingcheng Mao. Fetal liver tissues were obtained with Use of Non-Identifiable Biological Specimens/Data and so exempt from Human Subjects review. Human liver tissue samples were obtained from the UW School of Pharmacy Human Liver Bank (Seattle, WA) [13].

\section{Immunocytochemistry}

Cells on day 17 of differentiation were fixed with ice-cold methanol for 10-15 minutes, washed with PBS, and permeabilized with $0.5 \%$ Triton X-100 for 2 minutes. Following a PBS wash, cells were blocked with $2 \%$ normal goat serum for 1 hour at room temperature. Cells were then washed with PBS again and incubated overnight at $4{ }^{\circ} \mathrm{C}$ with the following primary antibodies: anti-AFP at 1:600 (Dako, Carpinteria, CA); antialbumin at 1:1000 (a gift from Dr. Jean Campbell, Department of Pathology, University of Washington); anti-HNF4 $\alpha$ at 1:100 (Santa Cruz Biotechnology, Dallas, TX); and anti-CYP3A at 1:100 (Santa Cruz Biotechnology). After washing with PBS, cells were incubated with Alexa Fluor ${ }^{\circledR} 488$ secondary antibodies at 1:1000 for 1 hour at room temperature (Invitrogen). Finally, cells were mounted with SlowFade ${ }^{\circledR}$ Gold Antifade Mount with DAPI (Invitrogen).

\section{DNA Isolation and Genotyping}

Genomic DNA was isolated from the WiCell ${ }^{\circledR}$ hESC lines using the Qiagen (Valencia, California) DNeasy blood and tissue kit according to the manufacturer's recommendations. DNA was quantified on a BioRad SmartSpec Plus (Hercules, CA) spectrophotometer, measuring absorbance and 260/280 nm ratio. Genotyping of hESC lines H1, H7, H9, H13, and H14 was conducted using the Affymetrix DMET ${ }^{\mathrm{TM}}$ Plus Array according to manufacturer's recommendations (Santa Clara, CA, http://www.affymetrix.com). Analysis was performed using Affymetrix's DMET ${ }^{\mathrm{TM}}$ Console Analysis Software.

\section{Quantitative real-time PCR ( $q R T-P C R)$ and CYP2D6 Copy Number Assay}

RNA was isolated using TRIzol Reagent from Invitrogen (Carlsbad, CA) following manufacturer's recommendations, and quantified on a BioRad SmartSpec Plus (Hercules, CA) spectrophotometer, measuring absorbance and 260/280 nm ratio. Complementary DNA (cDNA) was synthesized using $1 \mu \mathrm{g}$ total RNA and the Taqman ${ }^{\circledR}$ Reverse Transcription Reagents in $10 \mu \mathrm{L}$ total volume (Invitrogen). Following synthesis, CDNA was diluted to $5 \mathrm{ng} / \mu \mathrm{L}$ and $20 \mathrm{ng}$ was used for qRT-PCR analysis. qRT-PCR for CYPs 3A4, 3A7, 1A2, 1B1, 2A6, 2B6, 2C9, 2C19, 2C8, 2D6, 2E1, FMO1, FMO3, UGT1A1, UGT1A6, UGT2B4, UGT2B7, GSTT1, GSTM1, GSTP1, OATP1B1, OATP1B3, MRP2, ABCB1, ABCG2, ATP7B, NANOG, SOX2, OCT4, ALB, AFP, HNF4 $\alpha, C A R, P X R, A H R$, and POR was carried out using Taqman ${ }^{\circledR}$ Gene Expression Assays from Applied Biosystems (Foster City, California) with GUSB as the housekeeping gene. CYP2D6 copy number was 
assessed using a TaqMan ${ }^{\circledR}$ Copy Number assay from Applied Biosystems (Hs00010001_cn) with RNAseP as a single copy gene calibrator, according to the manufacturer's recommendations, using their SDS 2.3 and Copy Caller v1.0 programs. One copy and more than two copy positive controls were identified in the UW School of Pharmacy Human Liver Bank (Seattle, WA) through sequencing analysis as previously described.

\section{CYP2D6*41 reverse-transcription PCR Assay}

Total RNA was isolated using TRIzol Reagent (Invitrogen), following manufacturer's recommendations, and quantified on a BioRad SmartSpec Plus (Hercules, CA) spectrophotometer, measuring absorbance and 260/280 nm ratio. cDNA was synthesized using the TaqMan Reverse Transcription kit (Invitrogen) from $1 \mu \mathrm{g}$ of total RNA. To detect the presence of exon 6 in CYP2D6, a 579-bp PCR fragment spanning a region from exon 5 to exon 8 was amplified with primers Exon5/8For3 (5'-TCCCCGTCCTCCTGCATA-3') and Exon5/8Rev3 (5'-GTGTTCGGGGTGGAAGCG-3') (IDT, Coralville, lowa). If exon 6 is skipped due to the presence of CYP2D6*41, a smaller PCR fragment of 438-bp is expected. PCR was run under the following conditions, 95 ${ }^{\circ} \mathrm{C}$ for 5 minutes, $92{ }^{\circ} \mathrm{C}$ for 20 seconds, $59.6{ }^{\circ} \mathrm{C}$ for 30 seconds, $72{ }^{\circ} \mathrm{C}$ for 2 minutes, $72{ }^{\circ} \mathrm{C}$ for 10 minutes, 4 ${ }^{\circ} \mathrm{C}$ hold, repeating steps 2-4 for 40 cycles. PCR products were run on $1.5 \%$ agarose gels and visualized by staining with $0.5 \mu \mathrm{g} / \mathrm{mL}$ ethidium bromide (BioRad). Human liver samples used for this study were obtained from the UW School of Pharmacy Human Liver Bank. Genotyping for CYP2D6*41 was done using an existing TaqMan $^{\circledR}$ assay (C_34816116) (Applied Biosystems).

\section{CYP cocktail assay and LC-MS/MS}

Two CYP cocktail assays developed in Dr. Jashvant Unadkat's lab at the University of Washington were used to assess functional CYP activity [14]. Cocktail A assesses CYPs 3A, 2C9, 1A, 2D6, 2A6, and cocktail B assesses CYPs 2B6, 2C8, and 2E1. Acetaminophen, amodiaquine dihydrochloride dihydrate, bupropion, chlorzoxazone, coumarin, phenacetin, and tolbutamide were purchased from Sigma. Dextromethorphan, d5-diazepam, dextrorphan, testosterone, n-desethylamodiaquine, hydroxy-bupropion, 4hydroxytolbutamide, 6-hydroxychlorzoxazone, and 6- $\beta$-hydroxytestosterone were purchased from Cerilliant (Round Rock, TX). 7-hydroxycoumarin was a kind gift from Dr. Unadkat's lab.

For the analytical assays, a set of metabolite standards with nine calibration points and a separate set of three quality control (QC) samples were prepared. The calibrator concentration ranges were: acetaminophen, 0.031-8 $\mu \mathrm{M}$; OH-bupropion, 0.002-0.5 $\mu \mathrm{M}$; 4-OH-tolbutamide, 0.013-3.3 $\mu \mathrm{M}$; 6-OHtestosterone, 0.31-80 $\mu \mathrm{M}$; 6-OH-chlorzoxazone, 0.0625-16 $\mu \mathrm{M}$; 7-OH-coumarin, 0.0042-1.08 $\mu \mathrm{M}$; $\mathrm{n}$ desethylamodiaquine, 0.0083-2.12 $\mu \mathrm{M}$; dextrorphan, 0.0017-0.44 $\mu \mathrm{M}$. The $\mathrm{QC}$ concentration ranges were: acetaminophen, 0.125-4 $\mu \mathrm{M}$; OH-bupropion, 0.0078-0.25 $\mu \mathrm{M}$; 4-OH-tolbutamide, 0.052-1.66 $\mu \mathrm{M}$; 6-OHtestosterone, 1.25-40 $\mu \mathrm{M}$; 6-OH-chlorzoxazone, 0.25-8 $\mu \mathrm{M}$; 7-OH-coumarin, 0.017-0.54 $\mu \mathrm{M}$; $\mathrm{n}$ desethylamodiaquine, 0.033-1.06 $\mu \mathrm{M}$; dextrorphan, 0.0068-0.22 $\mu \mathrm{M}$. All calibrator and QC points were made in hepatozyme maturation media, an equal volume of calibrator or QC was then added to an equal volume of acetonitrile containing $0.06 \mathrm{ng} / \mu \mathrm{L}$ of internal standard $\mathrm{d} 5$-diazepam and centrifuged at 13,000 rpm for 10 minutes. The supernatant was removed and stored at $4{ }^{\circ} \mathrm{C}$ until analysis.

CYP assay incubations were performed on Day 17 SCDHs and cryopreserved hepatocytes lots HUM4012 and HUM4034. Incubations were performed as described by Liu et al., with some modifications [14]. Briefly, standard stock mixtures of cocktail $A$ and $B$ were prepared and diluted in hepatozyme maturation media for cell incubations to the following final concentrations: Cocktail $A$, tolbutamide, $75 \mu \mathrm{M}$, testosterone, 100 $\mu \mathrm{M}$, dextromethorphan, $5 \mu \mathrm{M}$, coumarin, $0.5 \mu \mathrm{M}$, phenacetin, $50 \mu \mathrm{M}$; Cocktail B, bupropion, $100 \mu \mathrm{M}$, amodiaquine, $4 \mu \mathrm{M}$, chlorzoxazone, $25 \mu \mathrm{M}$. The final concentration of organic solvent in cell incubations was $1 \%$. Cocktail incubations with SCDHs were performed for 2 hours at $37^{\circ} \mathrm{C}$. At the end of the incubation 
period, the media was collected and added to an equal volume of acetonitrile containing $0.06 \mathrm{ng} / \mu \mathrm{L} \mathrm{d5-}$ diazepam. Cocktail incubations with cryopreserved hepatocytes were performed for 30 minutes or 1 hour at $37^{\circ} \mathrm{C}$, media was collected at the end of the incubation and added to an equal volume of acetonitrile containing d5-diazepam. All incubation samples were centrifuged at 13,000 rpm for 10 minutes. The supernatant was removed and stored at $4{ }^{\circ} \mathrm{C}$ until analysis.

The CYP assay metabolites were analyzed using an Agilent 6460 triple quadrupole mass spectrometer (Agilent Technologies, Santa Clara, CA) in the University of Washington Mass Spectrometry center as described by Liu et al., with minor modifications [14]. Briefly, HPLC separation was achieved using an Agilent XDB C18 $2.1 \times 150 \mathrm{~mm}, 5 \mu \mathrm{m}$ column. Compounds were eluted at a flow rate of $0.25 \mathrm{~mL} / \mathrm{min}$, using the following gradient of $0.1 \%$ formic acid in water (solvent $\mathrm{A}$ ) and $0.1 \%$ formic acid in acetonitrile (solvent B): for the first 1.5 minutes, $99 \%$ solvent A, a linear decrease to $70 \%$ solvent $A$ until 4 minutes, maintained at $70 \%$ solvent $A$ until 6 minutes, a linear decrease to $25 \%$ solvent $A$ until 9 minutes and held at $25 \%$ solvent $A$ until 13 minutes to wash and cycled back to initial conditions. The column was allowed to reequilibrate for 4 minutes before the next sample was injected.

\section{Results and Discussion}

The University of Wisconsin has made WiCell ${ }^{\circledR}$ lines available to researchers for well over a decade [15]. This has made them some of the most widely used hESC lines in research, and in particular the most commonly used hESC lines in SCDH research, specifically the H1 and H9 lines [11, 16-35]. To be useful in preclinical drug metabolism and toxicity screening, $\mathrm{SCDHs}$ must demonstrate consistent and reproducible activity of drug metabolism proteins, in particular the oxidative CYP enzymes. In addition, it would be ideal if SCDHs demonstrate metabolic activities comparable to human primary hepatocytes. We sought to further investigate the state of SCDHs as they compare to cryopreserved human hepatocytes, with emphasis on the expression and functional capacity of drug-metabolizing enzymes. In addition, when evaluating CYP activity versus primary hepatocytes, it's important to take pharmacogenetic variability into account. To demonstrate the utility of SCDHs in pharmacogenetic predictive screening, we also sought to genetically profile the commonly used WiCell ${ }^{\circledR}$ hESC lines, focusing on CYP2D6 in our analysis.

\section{Hepatocyte differentiation and gene expression}

Hepatocyte differentiation was performed using a published protocol [11, 12]. Briefly, this protocol is broken into three stages to induce hepatocyte differentiation: first the priming stage primes the cells to the definitive endoderm lineage $[11,33,36]$, secondly the differentiation stage induces hepatocyte differentiation to form hepatoblast cells, and finally the maturation stage allows for final differentiation and maturation of the resulting hepatocytes. This differentiation protocol yielded SCDHs which morphologically resemble hepatocytes by displaying the hepatocyte cuboidal morphology and bi-nucleated cells (Figure $1 \mathrm{~A}$ and B). In addition, the SCDHs were immunocytochemically positive for AFP, albumin, HNF4 $\alpha$ and CYP3A (Figure 1C). Positive immunocytochemical staining was uniform across the wells with the exception of colonies of cells that failed to differentiate.

In order to evaluate the maturity level of SCDHs and gain a better understanding of their potential utility in preclinical drug metabolism screens, gene expression profiling of select pluripotency markers, hepatocytes markers, transcription factors, drug-metabolizing enzymes and transporters was done. This expression profiling was performed for SCDHs at each stage of differentiation, hESCs, cryopreserved hepatocytes, HepaRG cells, human fetal liver tissue and human adult liver tissue. HepaRG cells are a cell line derived from a human adult hepatocarcinoma patient, which resemble the bi-potential hepatoblast cell 
[37-39]. These cells can be cultured in their hepatoblast, or undifferentiated state, and then undergo a differentiation process to form both biliary epithelial cells and hepatocytes [37-39]. HepaRG cells express many of the drug-metabolizing enzymes and more closely resemble primary hepatocytes than the commonly used HepG2 cells [39]. To determine if SCDHs retain stem cell characteristics, the pluripotency markers NANOG, OCT4 and SOX2 were evaluated. All results are reported as fold change compared to differentiated HepaRG cells, with GUSB as the housekeeping gene. From the gene expression profiling, NANOG, OCT4, and SOX2 expression dropped as differentiation progressed from stem cell to SCDHs (Figure 2), suggesting the cells are undergoing a differentiation process and are not retaining their pluripotency. Notably, expression of NANOG and OCT4 in SCDHs was similar to expression in differentiated HepaRG cells, which was below the level of expression in fetal liver tissue (Figure 2). SOX2 expression in SCDHs was more variable between the different cell lines, and ranged from 0.4 - to 15 -fold compared to differentiated HepaRG cells, while SOX2 expression in fetal liver tissue ranged from 0.4- to 7-fold compared to differentiated HepaRG cells. Expression of all three pluripotency markers was low in the adult human liver tissues evaluated.

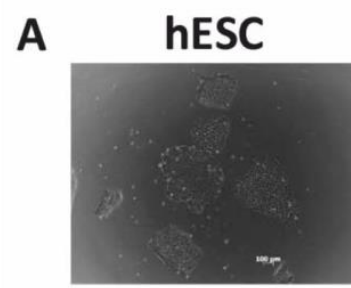

B

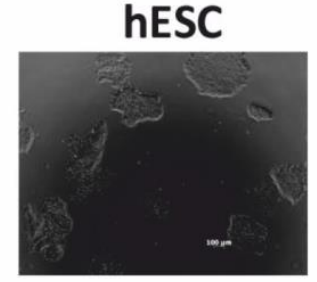

C

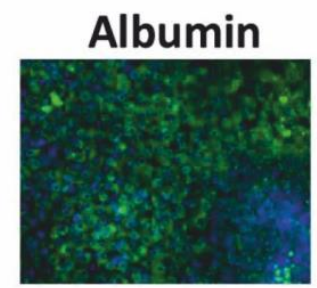

DE

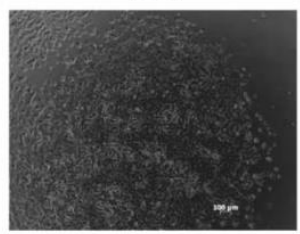

DE

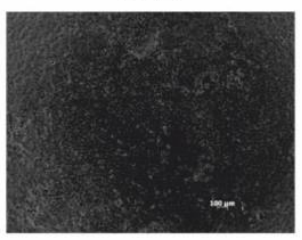

AFP

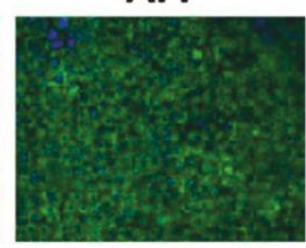

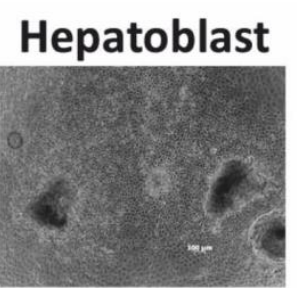

Hepatoblast

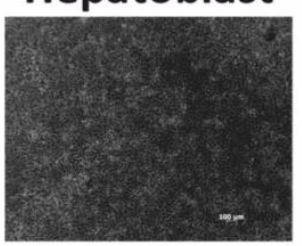

HNF4alpha

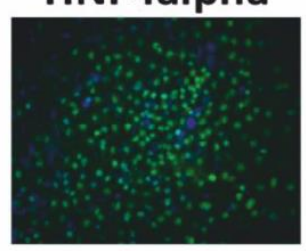

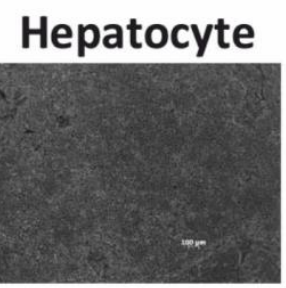

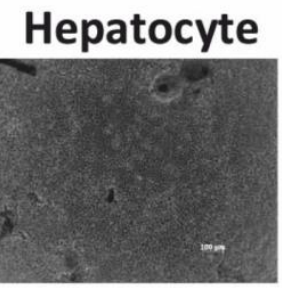

CYP3A

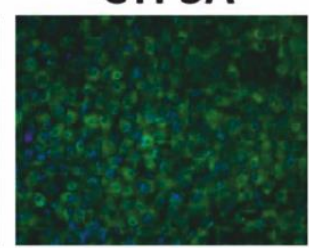

Figure 1. SCDH photomicrographs and immunocytochemistry. (A,B) Photomicrographs depicting $\mathrm{H} 1$ and $\mathrm{H} 9$ SCDHs, respectively, at each stage of differentiation; hESC, Definitive Endoderm (DE), Hepatoblast, and Hepatocyte. (C) Immunocytochemistry results for albumin, $\alpha$-fetoprotein (AFP), hepatocyte nuclear factor $4 \alpha$ (HNF4 $\alpha$ ), and CYP3A on Day 17 SCDHs. Positive staining is indicated in green, DAPI was used to stain nuclei, shown in blue.

A similar expression pattern was observed for three hepatocyte markers ( $A F P, A L B$ and $H N F 4 \alpha$ ), with expression increasing from stem cells through differentiation to SCDHs (Figure 2). For albumin, expression in SCDHs was lower than the expression in differentiated HepaRG cells, fetal and adult liver tissues. For $H N F 4 \alpha$, expression in SCDHs was comparable to expression in fetal and adult liver tissues, though lower than differentiated HepaRG cells (Figure 2). With regard to AFP, SCDHs expressed AFP to a much greater extent than differentiated HepaRG cells, ranging from 2800- to 13000-fold higher than HepaRG cells (Figure 2). Expression of AFP in fetal liver tissue ranged from 3600- to 30000-fold higher than HepaRG cells, indicating that SCDHs expressed AFP at levels comparable to fetal liver tissue. As expected, AFP expression 


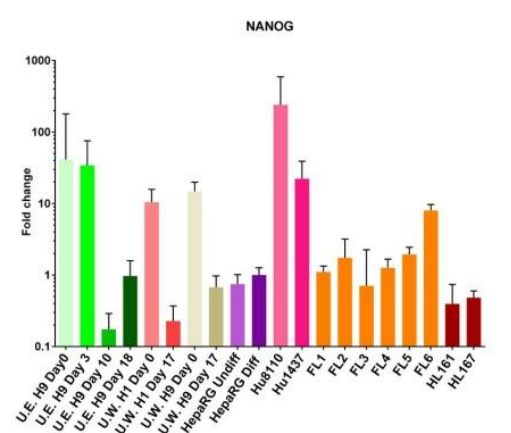

AfP

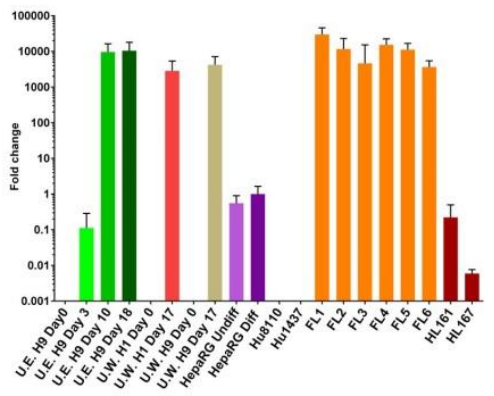

CYP3A4

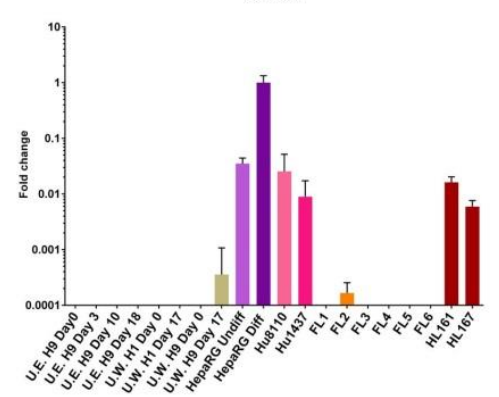

UGT2B7
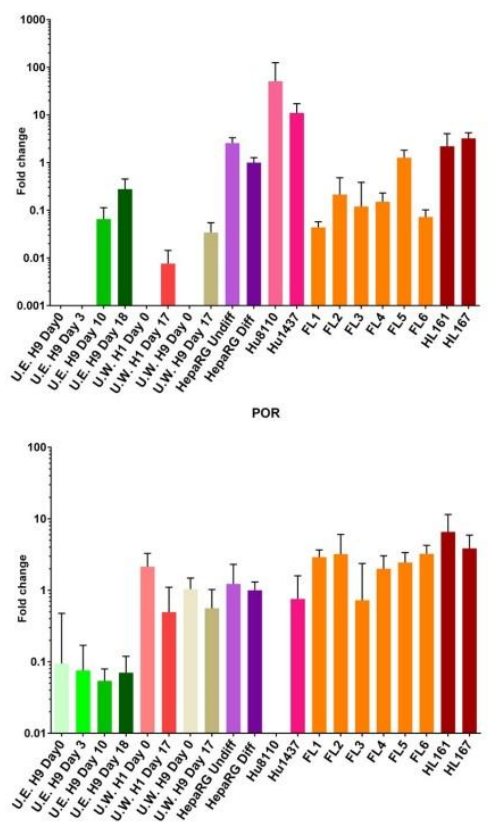

ост4

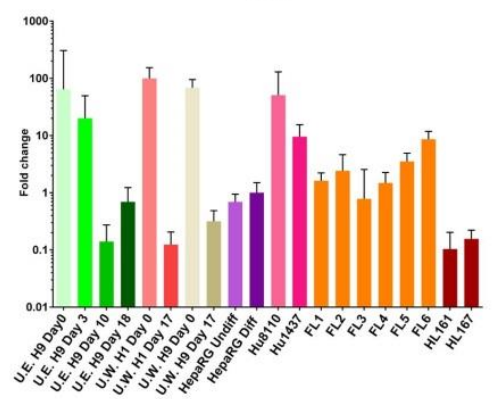

ALB

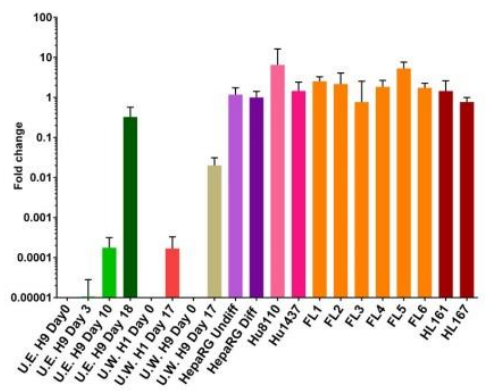

CYP3A7

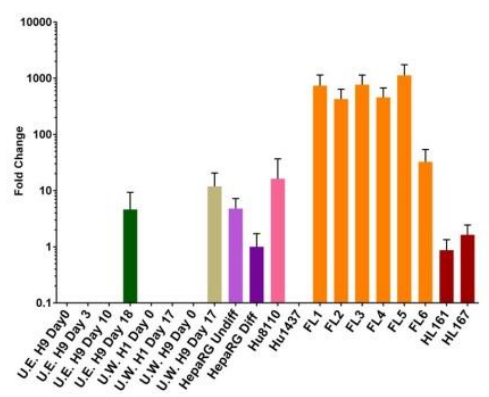

BCRP

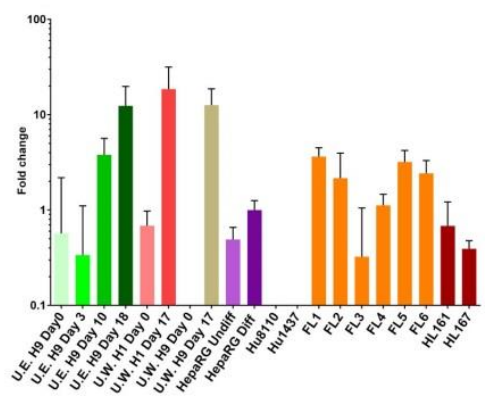

sox2

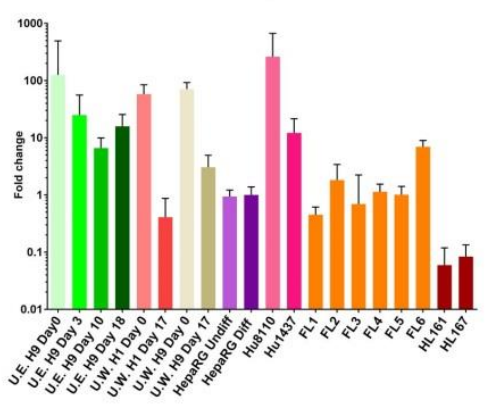

HNF4 $\alpha$

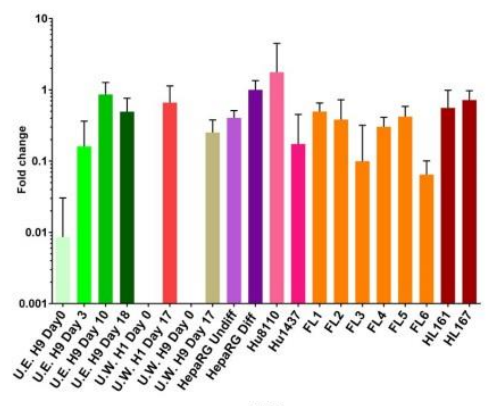

FMO1

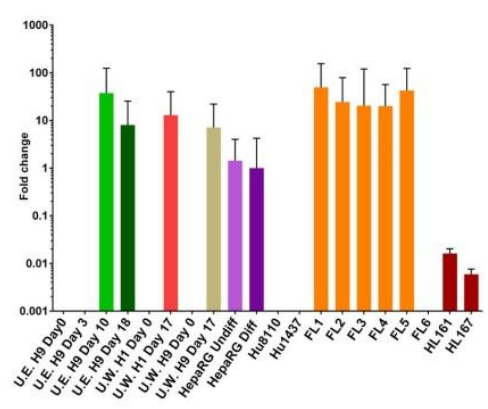

PgP

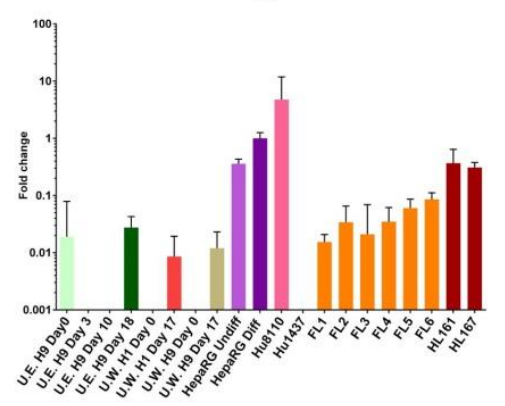

Figure 2. SCDH gene exp. characterization. qRT-PCR results shown as fold change compared to differentiated HepaRG cells, which was set to 1. GUS-B was used as a housekeeping gene. For all stem cell and SCDH samples, error bars represent a pool of triplicate biological replicates and triplicate technical replicates. For all other samples, error bars represent triplicate technical replicates. HepaRG Undiff represents undifferentiated HepaRG cells; HepaRG Diff represents differentiated HepaRG cells; FL1, FL2, FL3, FL4, FL5, FL6 represent fetal liver tissue 1, 2, 3, 4, 5, 6, respectively; HL161 and HL167 represent human liver bank samples 161 and 167 , respectively. 
was minimally expressed in adult liver tissues. The persistent expression of AFP in SCDHs is in accordance with published reports indicating a high retention of AFP expression in SCDHs. Overall, SCDHs appear to express the hepatocyte markers $A F P, A L B$, and $H N F 4 \alpha$ at levels comparable to fetal liver tissue, indicating a close resemblance to a fetal state hepatocyte.

Transcription factors which regulate drug metabolizing enzymes and transporters were evaluated. The transcription factors constitutive androstane receptor (CAR), pregnane $X$ receptor (PXR) and aryl hydrocarbon receptor (AhR) were selected because they regulate many of the hepatic phase I and II drugmetabolizing enzymes and transporters [40,41]. The expression of CAR, PXR and AhR in SCDHs was minimal (Supplemental Figure 1). The expression of AhR in SCDHs was comparable to that in fetal liver tissues, while the expression of CAR and PXR in SCDHs was lower than that in fetal liver tissues.

The expression of CYPs and flavin containing monooxygenases (FMO) were evaluated. With regard to FMOs, FMO1 is normally expressed to a greater extent in the fetal liver, and so can be used as another marker to evaluate how fetal-like SCDHs are. Indeed, from gene expression profiling FMO1 was highly expressed in fetal liver tissue, at levels 20- to 50-fold higher than that in differentiated HepaRG cells, while FMO1 expression was undetected in adult liver tissues (Figure 2). FMO1 expression in SCDHs increased through differentiation, up to 7- to 13- fold higher than differentiated HepaRG cells (Figure 2). While SCDHs retain high expression of FMO1, it was lower than that in fetal liver tissue. The CYP enzymes CYP3A4 and CYP3A7 also exhibit differential expression between fetal and adult liver, with CYP3A7 being the predominant isoform in fetal liver and CYP3A4 being predominant in the adult liver. This pattern was also observed between our fetal and adult liver tissue samples. CYP3A4 was detected in only one SCDH sample, with expression well below (0.0003-fold) that observed in HepaRG cells (Figure 2). CYP3A7 was detected in two SCDH samples, at 4.5- and 11.8-fold higher than HepaRG cells. Additionally, CYP3A7 expression in $\mathrm{SCDHs}$ was below expression levels in fetal liver tissue (Figure 2). From these data, SCDHs retain expression of CYP3A7, though CYP3A7 expression was lower than fetal liver tissue, indicating an overall lack of CYP3A expression in SCDHs. CYP 1A2, 2C19 and 2D6 were undetectable in SCDHs (Supplemental Figure 1). CYP2A6 was expressed in SCDHs, at levels slightly above adult liver tissue, though below those observed in fetal liver tissue (Supplemental Figure 1). CYP2B6 was undetectable in fetal liver tissue samples, but was expressed in SCDHs, though at levels below adult liver tissue (Supplemental Figure 1). CYP 2C8, 2 C9 and 2E1 were detectable in SCDHs, but at levels much lower than expression in adult liver tissue, though comparable to expression in fetal liver tissue (Supplemental Figure 1). Overall, there was minimal expression of the hepatic CYP enzymes in SCDHs, with the exception of the fetal CYP3A7 enzyme. The low expression of CYP enzymes in SCDHs would result in low functional activity and was unexpected given that $H N F 4 \alpha$ was expressed at a level consistent with fetal and adult liver tissue. HNF4 $\alpha$ is known to have a role in supporting the constitutive expression of CYP enzymes in human hepatocytes [42]. Given the relative expression of HNF4 $\alpha$, we would expect higher CYP expression in the SCDHs. The expression of P450 oxidoreductase $(P O R)$ was also evaluated. POR is essential for normal function of the CYP enzymes - it is needed for electron transfer from NADPH to the CYP $[43,44]$. POR expression in SCDHs was below that expressed in HepaRG differentiated cells, ranging from 0.07- to 0.56-fold (Figure 2). This expression was also well below that found in fetal and adult liver tissues (Figure 2). Interestingly, the undifferentiated hESC samples exhibited higher POR expression than SCDHs. A potential reason for the higher expression of POR in stem cells could be its use in supporting other CYP enzymes. For example, CYP26 plays an important role in embryonic stem cells to promote cell differentiation through retinoid signaling [45, 46]. The low expression of $P O R$ in SCDHs may contribute to the observed low functional activity for the drugmetabolizing CYP enzymes. 
To examine expression of phase II drug-metabolizing enzymes, UDP-glucuronosyltransferases (UGT) and glutathione-S-transferases (GST) were evaluated. Expression of UGT2B7 in SCDHs was comparable to fetal liver tissue (Figure 2). Expression of UGT1A1 in SCDHs was comparable to expression in both fetal and adult liver tissue and UGT1A6 expression was comparable to that in adult liver tissue (Supplemental Figure 1). In contrast, expression of UGT2B4 in SCDHs was below that of both fetal and adult liver tissue (Supplemental Figure 1). In general, for GSTT1, GSTM1 and GSTP1 there was largely no difference in expression between stem cells and SCDHs (Supplemental Figure 1). For the $\mathrm{H} 1$ and $\mathrm{H} 9$ cell lines evaluated in the gene expression profiling, no polymorphisms for the GSTs were detected in the DMET genotyping analysis.

To examine the expression of drug transporters in SCDHs, P-gp, BCRP, MRP2, OATP1B1, OATP1B3, and ATP7B mRNA levels were measured. $A T P 7 B$ is a copper transporting ATPase expressed in the liver, and is responsible for transporting copper from hepatocytes into the bile [47]. Mutations in ATP7B are associated with Wilson's disease, a disorder in copper metabolism with manifestations in the liver and the brain [47]. Expression of ATP7B was up-regulated in SCDHs, compared to stem cells. The expression in SCDHs was slightly higher than differentiated HepaRG cells, fetal and adult liver tissue (Supplemental Figure 1). P-gp was expressed in SCDHs at levels comparable to that in fetal liver tissue and below HepaRG differentiated cells and adult liver tissue (Figure 2). BCRP expression was higher in SCDHs compared to HepaRG cells, fetal and adult liver tissue (Figure 2). Expression of OATP1B1 and OATP1B3 was minimal in SCDHs, and well below that in fetal and adult liver tissue (Supplemental Figure 1). Lastly, while MRP2 mRNA was detected in SCDHs, it was below the expression levels in HepaRG cells, fetal and adult liver tissue (Supplemental Figure 1). Similar to the other results obtained for gene expression, some transporters were minimally expressed (OATP1B1, OATP1B3, MRP2), while some were similar to that in fetal liver tissue ( $P$-gp and ATP7B), with the exception of BCRP which was highly expressed in SCDHs.

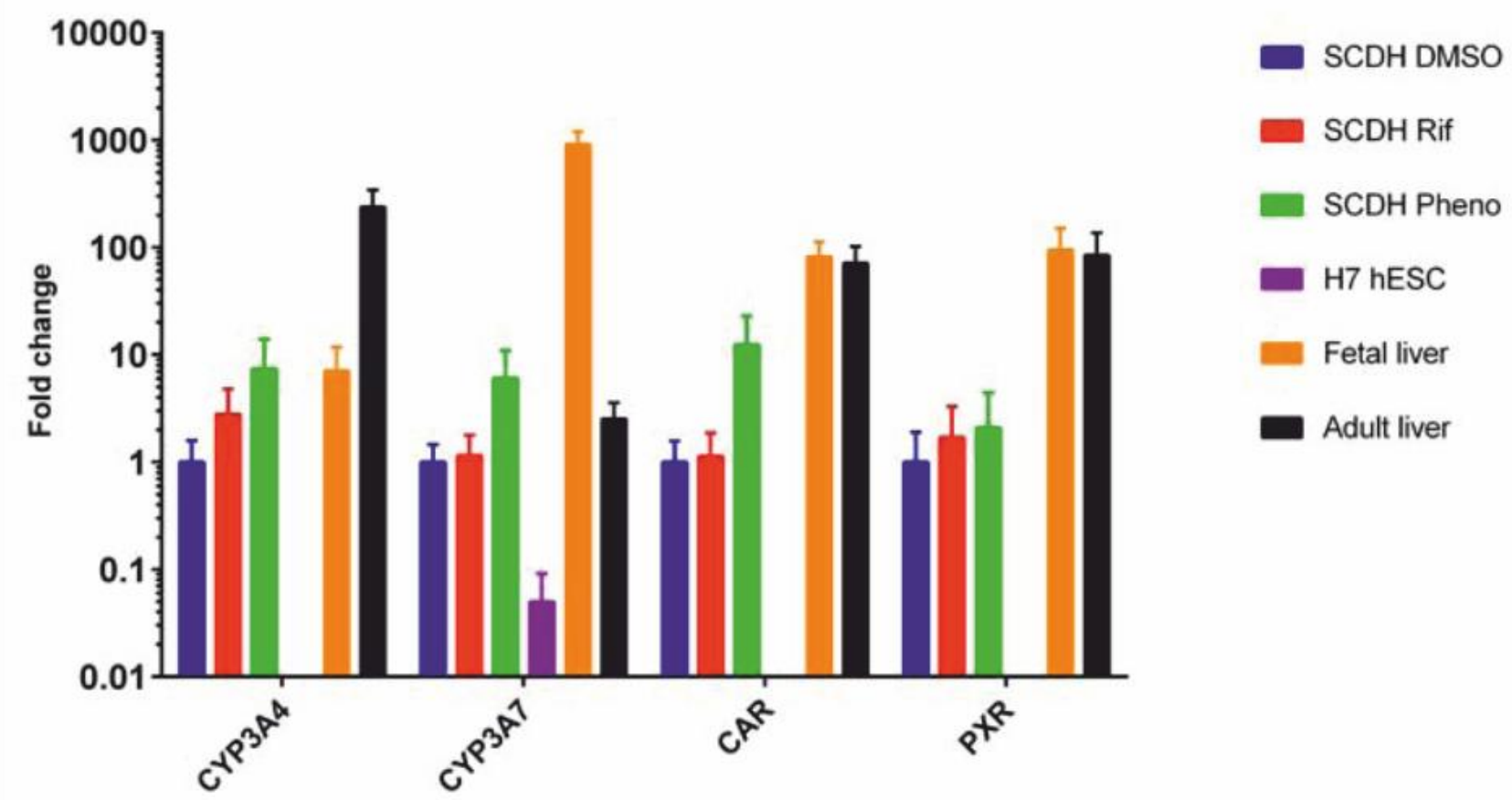

Figure 3. CYP3A induction. qRT-PCR results for SCDHs incubated with the inducer rifampicin or phenobarbital, shown as fold change compared to SCDHs incubated with DMSO, which was set to 1. GUS-B was used as a housekeeping gene. SCDH Rif represents SCDHs incubated with rifampicin; SCDH Pheno represents SCDHs incubated with phenobarbital.

SCDHs were incubated with the canonical inducers rifampicin and phenobarbital and effects on CYP3A4, CYP3A7, CAR and PXR expression were evaluated. Results are reported as fold change compared to SCDHs 
incubated with a DMSO vehicle control (Figure 3). In this instance, basal expression of CYPS $3 A 4$ and $3 A 7$ was detected in SCDHs. CYP3A4 expression was induced by rifampicin and phenobarbital. Phenobarbital induced CYP3A4 in SCDHs to levels comparable with a fetal liver tissue sample. CYP3A7 and CAR expression was induced by phenobarbital. Phenobarbital induced CYP3A7 in SCDHs to levels comparable with an adult liver tissue sample. The gene expression results reported here indicate SCDHs are capable of responding to the inducers rifampicin and phenobarbital.

Overall, gene expression profiling of SCDHs indicates they are largely immature hepatocytes, especially with regard to the CYP enzymes. With regards to AFP, CYP3A7 and FMO1 expression, SCDHs appear to more closely resemble fetal hepatocytes. This suggests that even though SCDHs are not currently in a fully differentiated, or mature, state they may be useful in studying drug-metabolism in neonates, or potentially as a test system to investigate the ontogeny of drug-metabolizing enzymes. However, further investigation of drug-metabolizing enzyme expression throughout the differentiation process and comparison to a more extensive sampling of fetal tissues at different ages than what was utilized in this study would be warranted. If SCDHs are to be used in conjunction with, or as an alternative to, cryopreserved hepatocytes a differentiation protocol that generates more mature hepatocytes is needed. One potential method that may enhance SCDH differentiation includes the use of small molecules in place of less chemically defined proteins. Another method that may enhance SCDH differentiation is the manipulation of microRNAs (miRNAs) during the cell culture process that contribute to hepatocyte development. miRNAs regulate many genes, making them similar to transcription factors, and therefore potential regulators of cellular processes such as differentiation. For example, knockdown of miRNAs that may contribute to maintenance of a pluripotent, or stem cell state, may allow further maturation of SCDHs. Alternatively, over-expression of miRNAs known to normally be expressed in mature hepatocytes may also allow for further maturation of SCDHs. Lastly, there is the potential of 3D culture systems to enhance SCDH differentiation and functional maturation. Culturing the SCDHs in a 3D, or microphysiological, culture system that more closely represents the true in vivo micro-environment of a hepatocyte is another potential method to enhance SCDH differentiation.

\section{CYP cocktail assay}

To assess the metabolic function of the CYP enzymes in SCDHs, a CYP cocktail assay was utilized and metabolite formation was measured using LC-MS/MS. For SCDHs, all metabolites were below the lower limit of quantitation (LLOQ) with the exception of 6-OH-testosterone, indicating some measurable activity of CYP3A (Table 1). 6-OH-testosterone was detectable for both $\mathrm{H} 1$ and $\mathrm{H} 9 \mathrm{SCDHs}$, with activity at 1.27 $\mathrm{pmol} / \mathrm{min} / 10^{6}$ cells. In contrast, activity in primary hepatocytes was $92.9 \mathrm{pmol} / \mathrm{min} / 10^{6}$ cells. The LLOQ for 6-OH-testosterone was $0.312 \mu \mathrm{M}$. Positive control primary and cryopreserved hepatocytes generated measurable metabolites for all compounds tested, indicating the incubation assay and LC-MS/MS method was working. Based on the CYP cocktail assay, SCDHs do not display detectable CYP activity, except for CYP3A, which was expected based on gene expression profiling. Overall, these results demonstrate an absence of functional drug-metabolizing enzyme activity in SCDHs, corroborating what has largely been reported for SCDHs to date; that they are immature compared to cryopreserved hepatocytes, especially with regards to drug-metabolizing enzyme functions.

\section{Genotyping}

We focused on CYP2D6 in our analysis in utilizing SCDHs for genotype-phenotype predictions, given its highly polymorphic nature and role in metabolizing about $20 \%$ of marketed drugs $[9,10]$. CYP2D6 is the most polymorphic drug-metabolizing enzyme, with more than 63 functional gene alleles 
(www.cypalleles.ki.se/cyp2d6.htm), including polymorphisms that result in gene deletion, defective splicing and gene duplication. Having an in vitro cell system, such as genotyped SCDHs, would allow for more thorough characterization of pharmacogenetic effects on drug metabolism, and potentially their impact on the pharmacokinetics of a new chemical entity early on in drug development. In particular, for compounds found to be highly metabolized by CYP2D6, where polymorphisms may lead to therapeutic failure or a drug toxicity risk, this may aid in making go/no-go decisions or help to inform possible inclusion of genotyping/phenotyping of patients in clinical studies. Select genotyping results for CYP2D6 can be found in Table 2. Analysis of CYP2D6 copy number found $\mathrm{H} 1$ to have 1 copy, with all other lines having 2 copies of CYP2D6. No CYP2D6 duplications were found, indicating there is no representative of a CYP2D6 ultra-rapid metabolizer within these cell lines (Table 2).

Table 1. CYP cocktail assay results. Results are reported as mean (SD). SCDH activity, $n=6$; primary hepatocyte activity, $\mathrm{n}=2$. LLOQ = lower limit of quantitation

\begin{tabular}{|l|c|c|c|}
\hline & LLOQ $(\mu \mathrm{M})$ & $\begin{array}{c}\text { SCDH activity (pmol/min/10 } \\
\text { cells) }\end{array}$ & $\begin{array}{c}\text { Primary Hepatocyte activity } \\
\text { (pmol/min/10 cells) }\end{array}$ \\
\hline CYP3A & 0.312 & $1.27(0.361)$ & $92.9(1.45)$ \\
\hline CYP1A & 0.125 & BLQ & $14.9(0.365)$ \\
\hline CYP2A6 & 0.0084 & BLQ & $0.0431(0.0168)$ \\
\hline CYP2B6 & 0.0039 & BLQ & $1.62(0.169)$ \\
\hline CYP2C8 & 0.017 & BLQ & $0.917(0.066)$ \\
\hline CYP2C9 & 0.013 & BLQ & $2.85(0.00544)$ \\
\hline CYP2D6 & 0.0017 & BLQ & $2.27(0.122)$ \\
\hline CYP2E1 & 1 & BLQ & $12.1(0.695)$ \\
\hline
\end{tabular}

Table 2. CYP2D6 genotyping results. A summary of the CYP2D6 copy number and genotyping results for WiCell ${ }^{\circledR}$ hESC lines $\mathrm{H1}, \mathrm{H7}, \mathrm{H} 9, \mathrm{H} 13$, and $\mathrm{H} 14$. Based on genotyping results a prediction for expected $\mathrm{CYP} 2 \mathrm{D} 6$ phenotype of each cell line was made. $\mathrm{PM}=$ poor metabolizer, $\mathrm{IM}=$ intermediate metabolizer, $\mathrm{EM}=$ extensive metabolizer.

\begin{tabular}{|c|c|c|c|c|c|c|}
\hline Common Name & $\begin{array}{l}\text { Probe Set } \\
\text { ID }\end{array}$ & H1 & $\mathrm{H7}$ & H9 & H13 & H14 \\
\hline Copy Number & & 1 & 2 & 2 & 2 & 2 \\
\hline $\begin{array}{l}\text { CYP2D6*2 } \\
2850 C>T\end{array}$ & AM_12261 & $\mathrm{T}$ & $\mathrm{C} / \mathrm{T}$ & $\mathrm{C} / \mathrm{T}$ & $\mathrm{T} / \mathrm{T}$ & $\mathrm{C} / \mathrm{T}$ \\
\hline $\begin{array}{l}\text { CYP2D6*3 } \\
\text { 2549delA }\end{array}$ & AM_12267 & $A$ & $A / A$ & $A / A$ & $A / A$ & $A / A$ \\
\hline $\begin{array}{l}\text { CYP2D6*4 } \\
1846 G>A\end{array}$ & AM_12274 & G & $\mathrm{G} / \mathrm{A}$ & G/G & $\mathrm{G} / \mathrm{G}$ & $\mathrm{G} / \mathrm{A}$ \\
\hline $\begin{array}{l}\text { CYP2D6*6 } \\
\text { 1707delT }\end{array}$ & AM_12276 & $\mathrm{T}$ & $\mathrm{T} / \mathrm{T}$ & $\mathrm{T} / \mathrm{T}$ & $\mathrm{T} / \mathrm{T}$ & $\mathrm{T} / \mathrm{T}$ \\
\hline $\begin{array}{l}\text { CYP2D6*9 } \\
\text { 2613_2615delAGA }\end{array}$ & AM_12264 & AGA & AGA/AGA & AGA/AGA & AGA/AGA & AGA/AGA \\
\hline $\begin{array}{l}\text { CYP2D6*10 } \\
100 C>T\end{array}$ & AM_12285 & $\mathrm{C}$ & $\mathrm{C} / \mathrm{T}$ & $\mathrm{C} / \mathrm{T}$ & $\mathrm{C} / \mathrm{C}$ & $\mathrm{C} / \mathrm{T}$ \\
\hline $\begin{array}{l}\text { CYP2D6*17 } \\
1023 C>T\end{array}$ & AM_12280 & C & $\mathrm{C} / \mathrm{C}$ & $\mathrm{C} / \mathrm{C}$ & $\mathrm{C} / \mathrm{C}$ & $\mathrm{C} / \mathrm{C}$ \\
\hline $\begin{array}{l}\text { CYP2D6*29 } \\
3183 G>A\end{array}$ & AM_12255 & G & $\mathrm{G} / \mathrm{G}$ & $\mathrm{G} / \mathrm{G}$ & $\mathrm{G} / \mathrm{G}$ & $\mathrm{G} / \mathrm{G}$ \\
\hline $\begin{array}{l}\text { CYP2D6*35 } \\
4180 G>C\end{array}$ & AM_12247 & $\mathrm{C}$ & $\mathrm{C} / \mathrm{C}$ & $\mathrm{C} / \mathrm{C}$ & $\mathrm{C} / \mathrm{C}$ & $\mathrm{C} / \mathrm{C}$ \\
\hline $\begin{array}{l}\text { CYP2D6*41 } \\
\text { 2988G>A }\end{array}$ & AM_12257 & $A$ & $\mathrm{G} / \mathrm{G}$ & $\mathrm{G} / \mathrm{A}$ & $\mathrm{G} / \mathrm{G}$ & $\mathrm{G} / \mathrm{G}$ \\
\hline $\begin{array}{l}\text { Predicted } \\
\text { Phenotype }\end{array}$ & & PM-IM & IM & IM-EM & EM & IM \\
\hline
\end{tabular}


Lines $\mathrm{H} 7$ and $\mathrm{H} 14$ were both found to have one copy of the CYP2D6*4 null allele, with no other polymorphisms associated with aberrant function detected. With regard to the CYP2D6*41 allele, line H9 was found to be heterozygous for this allele, and the single gene copy of CYP2D6 in line $\mathrm{H} 1$ also contains the CYP2D6*41 allele. Taking the copy number and genotyping data together, we have made predictions regarding CYP2D6 phenotype in these cell lines, as found in Table 2. To summarize, we predict line $\mathrm{H} 1$ to be a CYP2D6 poor-intermediate metabolizer, lines $\mathrm{H} 7$ and $\mathrm{H} 14$ to be intermediate metabolizers, line $\mathrm{H} 9$ to be an intermediate-extensive metabolizer, depending on activity from the CYP2D6*41 allele, and line $\mathrm{H} 13$ to be an extensive metabolizer. Select genotyping results for other CYP enzymes can be found in Table 3 . Notably, all $5 \mathrm{hESC}$ lines were found to be homozygous for $\mathrm{CYP} 3 \mathrm{~A} 5^{*} 3$, a null allele, meaning they are all CYP3A5 non-expressers. In addition, the $\mathrm{H} 14$ line is homozygous for CYP2C9*2 and $\mathrm{H} 1$ is heterozygous for CYP2C9*3; both of these alleles result in decreased CYP2C9 activity and have documented effects on in vitro and in vivo pharmacokinetics and clinical drug response, e.g. warfarin [48]. Genotyping results for Phase II/III enzymes can be found in Table 4. Lines H7, H13, and H14 are heterozygous for the UGT1A1*28 allele, which results in reduced activity of UGT1A1 [49]. Clinically, reduced activity of the UGT1A1*28 allele is associated with development of toxicity following administration of the chemotherapeutic irinotecan (The Pharmacogenomics Knowledge Base: https://www.pharmgkb.org) [50]. Additionally, lines $\mathrm{H1}, \mathrm{H7}$, and $\mathrm{H} 14$ are heterozygous for the NAT2*5 allele and $\mathrm{H} 13$ is homozygous for this allele, likely resulting in slow acetylator status for these cell lines. The Affymetrix $\mathrm{DMET}^{\mathrm{TM}}$ array genotyping results in their entirety can be accessed from Gene Expression Omnibus (GEO): (http://www.ncbi.nlm.nih.gov/geo/query/acc.cgi?acc =GSE53889; accession: GSE53889).

Table 3. CYP genotyping results. A summary of CYP genotyping results for WiCell ${ }^{\circledR} \mathrm{hESC}$ lines $\mathrm{H} 1, \mathrm{H7}, \mathrm{H} 9, \mathrm{H} 13$, and $\mathrm{H} 14$.

\begin{tabular}{|c|c|c|c|c|c|c|}
\hline Common Name & $\begin{array}{c}\text { Probe Set } \\
\text { ID }\end{array}$ & H1 & H7 & H9 & H13 & H14 \\
\hline $\begin{array}{l}\text { CYP1A2*1F } \\
-163 C>A\end{array}$ & AM_10785 & $A / A$ & $\mathrm{C} / \mathrm{C}$ & $\mathrm{A} / \mathrm{C}$ & $\mathrm{C} / \mathrm{C}$ & $A / C$ \\
\hline $\begin{array}{l}\text { CYP2A6 } \\
\text { Deletion }\end{array}$ & CN_CYP2A6 & $\begin{array}{l}\text { One or } \\
\text { more }\end{array}$ & $\begin{array}{l}\text { One or } \\
\text { more }\end{array}$ & $\begin{array}{l}\text { One or } \\
\text { more }\end{array}$ & $\begin{array}{l}\text { One or } \\
\text { more }\end{array}$ & $\begin{array}{c}\text { One or } \\
\text { more }\end{array}$ \\
\hline $\begin{array}{l}\text { CYP2B6*5 } \\
25505 C>T\end{array}$ & AM_11426 & $\mathrm{C} / \mathrm{C}$ & $\mathrm{C} / \mathrm{T}$ & $\mathrm{C} / \mathrm{C}$ & $\mathrm{C} / \mathrm{T}$ & $\mathrm{C} / \mathrm{T}$ \\
\hline $\begin{array}{l}\text { CYP2B6*6 } \\
15631 G>T\end{array}$ & AM_11411 & $\mathrm{G} / \mathrm{G}$ & No Call & No Call & G/G & $\mathrm{G} / \mathrm{T}$ \\
\hline $\begin{array}{l}\text { CYP2C9*2 } \\
3608 C>T\end{array}$ & AM_10100 & $\mathrm{C} / \mathrm{C}$ & $\mathrm{C} / \mathrm{C}$ & $\mathrm{C} / \mathrm{C}$ & $\mathrm{C} / \mathrm{C}$ & $\mathrm{T} / \mathrm{T}$ \\
\hline $\begin{array}{l}\text { CYP2C9*3 } \\
42614 A>C\end{array}$ & AM_10113 & $\mathrm{A} / \mathrm{C}$ & $A / A$ & $A / A$ & $A / A$ & $A / A$ \\
\hline $\begin{array}{l}\text { CYP2C19*2 } \\
\text { 19154G>A }\end{array}$ & AM_10070 & $\mathrm{G} / \mathrm{G}$ & $\mathrm{G} / \mathrm{G}$ & $\mathrm{G} / \mathrm{G}$ & $\mathrm{G} / \mathrm{G}$ & $\mathrm{G} / \mathrm{G}$ \\
\hline $\begin{array}{l}\text { CYP2C19*3 } \\
17948 G>A\end{array}$ & AM_10068 & $\mathrm{G} / \mathrm{G}$ & $\mathrm{G} / \mathrm{G}$ & $\mathrm{G} / \mathrm{G}$ & $\mathrm{G} / \mathrm{G}$ & $\mathrm{G} / \mathrm{G}$ \\
\hline $\begin{array}{l}\text { CYP2C19*17 } \\
-806 C>T\end{array}$ & AM_10053 & $\mathrm{C} / \mathrm{T}$ & $\mathrm{C} / \mathrm{C}$ & $\mathrm{C} / \mathrm{T}$ & $\mathrm{C} / \mathrm{C}$ & $\mathrm{C} / \mathrm{C}$ \\
\hline $\begin{array}{l}\text { CYP2E1*2 } \\
1132 G>A\end{array}$ & AM_10249 & $\mathrm{G} / \mathrm{G}$ & G/G & $\mathrm{G} / \mathrm{G}$ & G/G & $\mathrm{G} / \mathrm{G}$ \\
\hline $\begin{array}{l}\text { CYP3A5*3 } \\
6986 A>G\end{array}$ & AM_14759 & $\mathrm{G} / \mathrm{G}$ & $\mathrm{G} / \mathrm{G}$ & $\mathrm{G} / \mathrm{G}$ & $\mathrm{G} / \mathrm{G}$ & $\mathrm{G} / \mathrm{G}$ \\
\hline $\begin{array}{l}\text { CYP3A5*6 } \\
14690 G>A\end{array}$ & AM_14748 & $\mathrm{G} / \mathrm{G}$ & $\mathrm{G} / \mathrm{G}$ & $\mathrm{G} / \mathrm{G}$ & $\mathrm{G} / \mathrm{G}$ & $\mathrm{G} / \mathrm{G}$ \\
\hline $\begin{array}{l}C Y P 3 A 7 * 1 C \\
-232 A>C\end{array}$ & AM_14791 & $A / A$ & $A / A$ & $A / A$ & $A / A$ & $A / A$ \\
\hline $\begin{array}{l}\text { CYP3A7*1C } \\
-284 T>A\end{array}$ & AM_14796 & $\mathrm{T} / \mathrm{T}$ & $\mathrm{T} / \mathrm{T}$ & $\mathrm{T} / \mathrm{T}$ & $\mathrm{T} / \mathrm{T}$ & $\mathrm{T} / \mathrm{T}$ \\
\hline $\begin{array}{l}\text { CYP3A7*2 } \\
26041 C>G\end{array}$ & AM_14781 & $\mathrm{C} / \mathrm{C}$ & $\mathrm{C} / \mathrm{C}$ & $\mathrm{C} / \mathrm{C}$ & $\mathrm{C} / \mathrm{C}$ & $\mathrm{C} / \mathrm{C}$ \\
\hline
\end{tabular}


For use in preclinical drug metabolism screening assays, vendors commonly offer pooled donor lots of hepatocytes to mitigate the effects of interindividual variability. With this in mind, the $\mathrm{H} 1$ line has one copy of CYP2D6, making it a predicted poor metabolizer in human hepatocytes, meaning SCDHs generated from hESC line H1 may not metabolize CYP2D6 probe drugs at a level comparable to primary hepatocytes. In this case it would be important to ensure that a lot of single donor human primary hepatocytes used for comparison with H1-derived SCDHs have been characterized as a CYP2D6 poor metabolizer. Regarding other CYP isozymes, a commonly used activity test in SCDHs is an ethoxyresorufin-O-deethylase (EROD) assay for CYP1A activity and inducibility $[11,19,51,52]$. Our genotyping results show the $\mathrm{H} 1$ line to be homozygous and $\mathrm{H} 9$ to be heterozygous for $C Y P 1 A 2 * 1 F$, an allele which has been shown to influence the magnitude of inducibility of CYP1A2 [48, 53].

Table 4. Phase II/III genotyping results. A summary of genotyping results for phase II and III enzymes for WiCell ${ }^{\circledR}$ hESC lines H1, H7, H9, H13, and H14.

\begin{tabular}{|c|c|c|c|c|c|c|}
\hline Common Name & $\begin{array}{c}\text { Probe Set } \\
\text { ID }\end{array}$ & H1 & H7 & H9 & H13 & H14 \\
\hline $\begin{array}{l}A L D H 2 \\
1510 G>A\end{array}$ & AM_10586 & $\mathrm{G} / \mathrm{G}$ & $\mathrm{G} / \mathrm{G}$ & G/G & $\mathrm{G} / \mathrm{G}$ & G/G \\
\hline $\begin{array}{l}\text { GSTM1 } \\
\text { Deletion }\end{array}$ & $\begin{array}{c}\text { CN_GSTM } \\
1\end{array}$ & $\begin{array}{c}\text { One or } \\
\text { more }\end{array}$ & 0 & $\begin{array}{l}\text { One or } \\
\text { more }\end{array}$ & 0 & 0 \\
\hline $\begin{array}{l}\text { GSTT1 } \\
\text { Deletion }\end{array}$ & CN_GSTT1 & $\begin{array}{c}\text { One or } \\
\text { more }\end{array}$ & $\begin{array}{c}\text { One or } \\
\text { more }\end{array}$ & $\begin{array}{c}\text { One or } \\
\text { more }\end{array}$ & $\begin{array}{c}\text { One or } \\
\text { more }\end{array}$ & $\begin{array}{c}\text { One or } \\
\text { more }\end{array}$ \\
\hline $\begin{array}{l}\text { NAT1*14 } \\
560 G>A\end{array}$ & AM_14978 & $A / G$ & G/G & G/G & G/G & $\mathrm{G} / \mathrm{G}$ \\
\hline $\begin{array}{l}\text { NAT2*5 } \\
341 T>C\end{array}$ & AM_15001 & $\mathrm{C} / \mathrm{T}$ & $C / T$ & $\mathrm{~T} / \mathrm{T}$ & $\mathrm{C} / \mathrm{C}$ & $\mathrm{C} / \mathrm{T}$ \\
\hline $\begin{array}{l}\text { SULT1A1*2 } \\
638 G>A\end{array}$ & AM_11005 & $A / G$ & $A / G$ & $A / G$ & G/G & $A / G$ \\
\hline $\begin{array}{l}T^{2} M T^{*} 2 \\
238 G>C\end{array}$ & AM_13986 & G/G & G/G & G/G & $\mathrm{G} / \mathrm{G}$ & $\mathrm{G} / \mathrm{G}$ \\
\hline $\begin{array}{l}\text { TPMT*3B } \\
\text { 460G }>A\end{array}$ & AM_13980 & $\mathrm{G} / \mathrm{G}$ & $\mathrm{G} / \mathrm{G}$ & $\mathrm{G} / \mathrm{G}$ & $\mathrm{G} / \mathrm{G}$ & $\mathrm{G} / \mathrm{G}$ \\
\hline $\begin{array}{l}\text { TPMT*3C } \\
719 A>G\end{array}$ & AM_13973 & $A / A$ & $A / A$ & $A / A$ & $A / A$ & $A / A$ \\
\hline $\begin{array}{l}T P M T^{*} 4 \\
626-1 G>A\end{array}$ & AM_13977 & $\mathrm{G} / \mathrm{G}$ & $\mathrm{G} / \mathrm{G}$ & $\mathrm{G} / \mathrm{G}$ & $\mathrm{G} / \mathrm{G}$ & $\mathrm{G} / \mathrm{G}$ \\
\hline $\begin{array}{l}\text { UGT1A1*28 } \\
\text { TATA-box }\end{array}$ & AM_13024 & $\begin{array}{l}\text { (TA)5or6/ } \\
\text { (TA)5or6 }\end{array}$ & $\begin{array}{l}\text { (TA)5or6/ } \\
\text { (TA)7or8 }\end{array}$ & $\begin{array}{l}\text { (TA)5or6/ } \\
\text { (TA)5or66 }\end{array}$ & $\begin{array}{l}\text { (TA)5or6/ } \\
\text { (TA)7or8 }\end{array}$ & $\begin{array}{l}\text { (TA)5or6/ } \\
\text { (TA)7or8 }\end{array}$ \\
\hline $\begin{array}{l}\text { UGT2B7*2 } \\
802 C>T\end{array}$ & AM_13465 & $T / T$ & $T / T$ & $T / T$ & $\mathrm{C} / \mathrm{T}$ & $T / T$ \\
\hline $\begin{array}{l}A B C B 1 \\
1236 C>T\end{array}$ & AM_14612 & $\mathrm{C} / \mathrm{T}$ & $\mathrm{C} / \mathrm{T}$ & $\mathrm{C} / \mathrm{T}$ & $C / T$ & $C / T$ \\
\hline $\begin{array}{l}A B C B 1 \\
2677 G>T>A\end{array}$ & AM_14592 & $\mathrm{G} / \mathrm{T}$ & $\mathrm{G} / \mathrm{T}$ & $\mathrm{G} / \mathrm{T}$ & $\mathrm{G} / \mathrm{T}$ & $\mathrm{G} / \mathrm{T}$ \\
\hline $\begin{array}{l}A B C B 1 \\
3435 C>T\end{array}$ & AM_14581 & $\mathrm{C} / \mathrm{T}$ & $C / T$ & $C / T$ & $\mathrm{C} / \mathrm{T}$ & $C / T$ \\
\hline $\begin{array}{l}A B C G 2 \\
421 C>A\end{array}$ & AM_13688 & $\mathrm{C} / \mathrm{C}$ & $\mathrm{C} / \mathrm{C}$ & $\mathrm{C} / \mathrm{C}$ & $\mathrm{C} / \mathrm{C}$ & $\mathrm{C} / \mathrm{C}$ \\
\hline $\begin{array}{l}\text { SLCO1A2 } \\
\text { 404A }>T\end{array}$ & AM_10533 & $A / A$ & $A / A$ & $A / A$ & $\mathrm{~A} / \mathrm{A}$ & $A / A$ \\
\hline $\begin{array}{l}\text { SLCO1A2 } \\
516 A>C\end{array}$ & AM_10531 & $\mathrm{A} / \mathrm{A}$ & $A / A$ & $A / A$ & $\mathrm{~A} / \mathrm{A}$ & $A / A$ \\
\hline $\begin{array}{l}S L C O 1 B 1 * 1 B \\
\text { 388A>G }\end{array}$ & AM_10496 & $A / G$ & $A / A$ & $A / G$ & $A / A$ & $\mathrm{~A} / \mathrm{A}$ \\
\hline $\begin{array}{l}\text { SLCO1B1*4 } \\
463 C>A\end{array}$ & AM_10498 & $\mathrm{C} / \mathrm{C}$ & $\mathrm{C} / \mathrm{C}$ & $\mathrm{A} / \mathrm{C}$ & $\mathrm{C} / \mathrm{C}$ & $\mathrm{C} / \mathrm{C}$ \\
\hline $\begin{array}{l}\text { SLCO1B3 } \\
334 G>T\end{array}$ & AM_10481 & G/G & G/G & G/G & G/G & G/G \\
\hline $\begin{array}{l}\text { SLCO1B3 } \\
699 A>G\end{array}$ & AM_10482 & $A / A$ & $A / A$ & $A / A$ & $A / A$ & $A / A$ \\
\hline
\end{tabular}


The genotyping data presented here is important to better understand the activity of metabolizing enzymes and transporters when evaluating metabolism of probe substrates in SCDHs, particularly when being used as a marker to evaluate the efficiency of differentiation of SCDHs. The Affymetrix DMET ${ }^{\mathrm{TM}}$ array used for genotyping in this study provides a thorough evaluation of the major known polymorphisms in ADME-related genes. However, there are examples when calls were not made (e.g. CYP2B6*6), such that if evaluating activity of these proteins, individual genotyping for these alleles may be necessary. This study only reports results for the five commonly used WiCell ${ }^{\circledR}$ lines, however this approach to genotyping should be considered for all hESC and human iPSC lines used as a target cell source for models of drug metabolism and toxicity. In particular, if a bank of hESC or iPSCs is to be established then the use of a genotyping array, such as the Affymetrix DMET ${ }^{\mathrm{TM}}$ array, should be implemented with results readily available to researchers. As the cost of whole genome sequencing continues to decrease, it will become an attractive alternative to targeted arrays such as what we employed, with the caveat that mining these large data sets for specific ADME-related polymorphisms is currently challenging.

\section{CYP2D6*41 reverse-transcription PCR Assay}

Aberrant splicing resulting from the CYP2D6*41 polymorphism was assessed ex vivo with human liver tissue and in vitro using SCDHs. To assess differentiation in the SCDHs used for CYP2D6*41 analysis, gene expression of AFP, ALB, HNF4 $\alpha, C Y P 2 D 6, C Y P 3 A 4, N A N O G$ and OCT4 was evaluated, results are reported as fold change compared to cryopreserved hepatocyte log HUM4012 (Figure 4A). While expression of $H N F 4 \alpha$ in SCDHs is comparable to that seen in cryopreserved hepatocytes, expression levels of albumin and CYP3A4 were lower than that of cryopreserved hepatocytes. Conversely, expression of AFP in SCDHs is higher than that expressed in cryopreserved hepatocytes, corroborating our previous gene expression results. Expression of NANOG and OCT4 in SCDHs was lower than expression in the undifferentiated hESC lines and comparable to cryopreserved hepatocytes. In the case of CYP2D6, expression levels were detectable in $\mathrm{H} 9 \mathrm{SCDHs}$, though below expression in cryopreserved hepatocytes, while H1 SCDHs were below the limit of quantitation. This differential expression is in line with the genotyping results for these two cell lines.

Earlier identification and characterization of the 2988G>A SNP, now referred to as CYP2D6*41 (Human CYP Allele nomenclature website: http://www.imm.ki.se/), revealed it to cause a splicing defect, resulting in exon 6 being skipped, and a predictor of CYP2D6 intermediate metabolizer phenotype [54-56]. Toscano et al. identified the splice variant lacking exon 6 in liver samples genotyped for CYP2D6*41 (2988G>A) and found that $2988 \mathrm{G}>\mathrm{A}$ causes favorable formation of a splice product that lacks exon 6 , with up to 7 -fold increased levels of the splice variant [55]. We wanted to further elucidate the penetrance of CYP2D6*41 aberrant splicing and, in addition, we wanted to demonstrate the potential utility of SCDHs to evaluate genotype-phenotype relationships for CYP2D6. Results from PCR amplification using primers Exon5/8For3 and Exon5/8Rev3 are shown in Figure $4 \mathrm{~B}$ and $\mathrm{C}$. The expected amplicons for samples homozygous for CYP2D6*41 are 438-bp, for heterozygous samples both 438-bp and 579-bp, and for non-carriers of CYP2D6*41 579-bp. As shown in Figure 4C, certain samples (lanes 1 and 2) homozygous for *41 have a 579bp amplicon as well as the expected 438-bp alternatively spliced band, indicating the unexpected presence of exon 6, and demonstrating incomplete penetrance of this splicing defect. In addition, one sample (lane 7) heterozygous for ${ }^{*} 41$ only displays the 579-bp amplicon, indicating presence of exon 6 in all mRNA produced (or suppression of expression of the * 41 allele). It should be noted that the aberrantly spliced band may be present, but simply was below the limit of detection in our RT-PCR assay. The H1 SCDH sample, with one copy of CYP2D6 containing *41 displays the expected exon 6 spliced band at 438-bp, as seen in Figure $4 C$, lane 13 . No properly spliced band was detected, as expected. Our SCDH CYP2D6*41 
heterozygous cell, line H9 (lane 14) also displays a band indicating aberrant exon 6 splicing, but only a weak band for the properly spliced transcript fragment. Again, bands may be present, but simply were below the limit of detection in our RT-PCR assay; based on observations from the qRT-PCR that CYP2D6 expression in $\mathrm{H} 1 \mathrm{SCDHs}$ is below the limit of quantitation and in H9 SCDHs is 16 fold lower than that of cryopreserved hepatocytes based on $\triangle \triangle C_{\mathrm{T}}$ calculations. We are able to show similar results for CYP2D6*41 splicing in our SCDHs as seen in the liver tissue samples. Overall, our results corroborate the findings of Toscano et al. and provide further evidence that CYP2D6*41 displays incomplete penetrance.

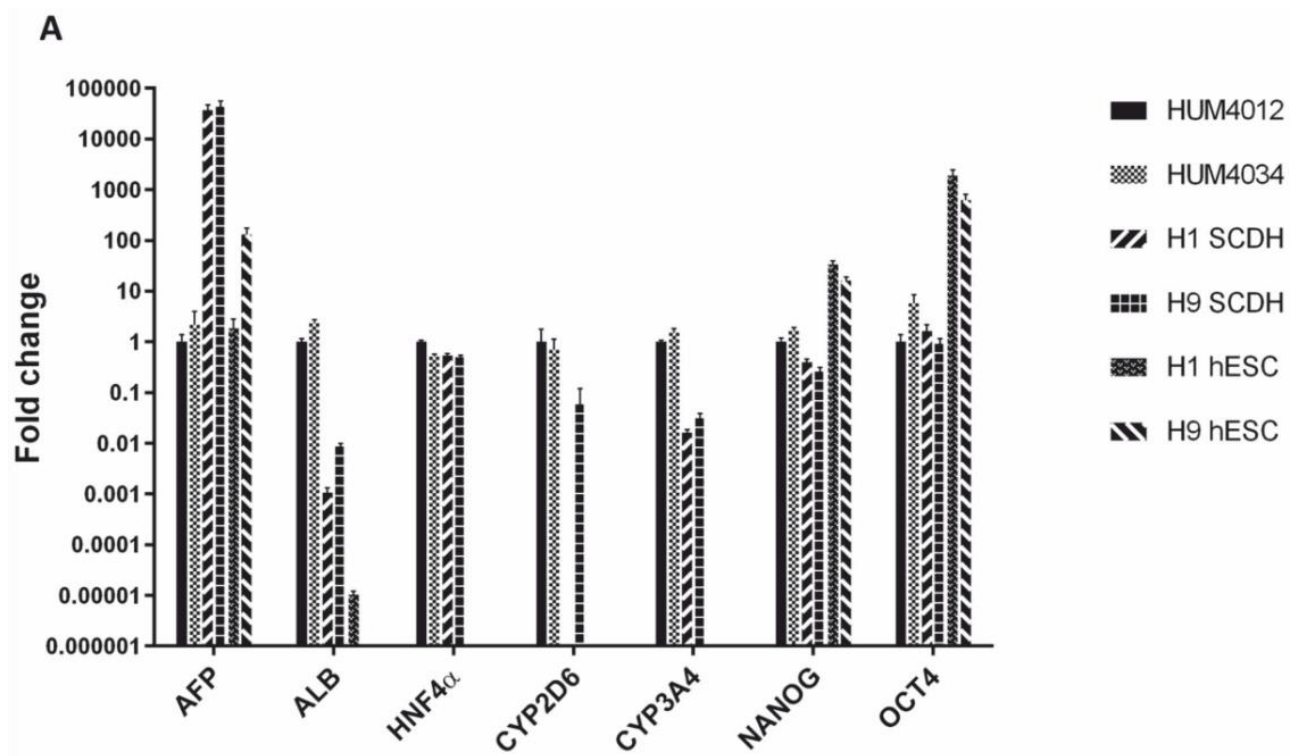

B

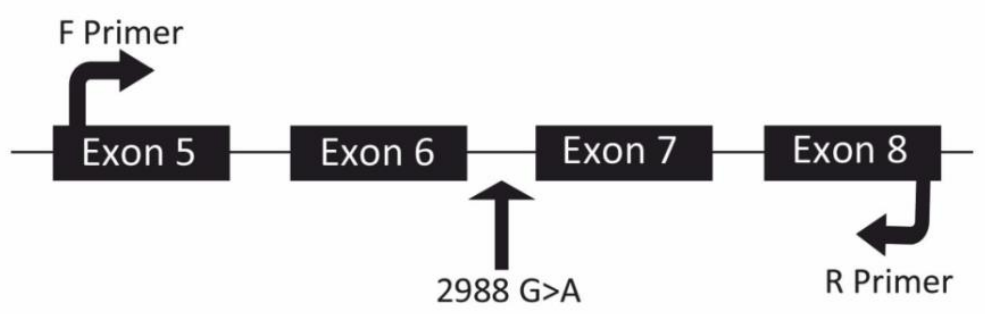

\section{CYP2D6*41 $\begin{array}{lll}\text { Exon } 5 & \text { Exon } 7 & \text { Exon } 8\end{array}$}

C

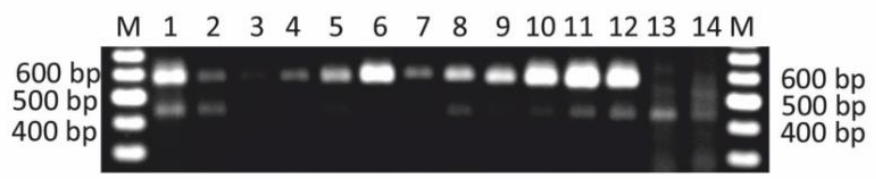

Figure 4. CYP2D6*41 reverse transcription PCR assay. (A) Gene expression results shown as fold change compared to cryopreserved hepatocyte lot HUM4012, which was set to 1. (B) Schematic representation of the CYP2D6 gene. The polymorphism of interest is 2988G>A located between exons 6 and 7 , and results in exon 6 skipping. To detect the presence of exon 6 in CYP2D6, a 579-bp PCR fragment spanning a region from exon 5 to exon 8 was amplified with primers Exon5/8For3 (F Primer) and Exon5/8Rev3 (R Primer). If exon 6 is

skipped due to the presence of CYP2D6*41, a smaller PCR fragment of 438-bp is expected. (C) Agarose electrophoretic analysis of reverse transcription PCR products of the CYP2D6 region indicated in (B) from human liver tissue samples and Day $17 \mathrm{SCDHs}$ generated from WiCell ${ }^{\circledR}$ lines $\mathrm{H} 1$ and $\mathrm{H} 9$. Lane $\mathrm{M}, 100 \mathrm{bp}$ marker; lane $1 * 41 / * 41$; lane $2 * 41 / * 41$; lane $3 * 1 A /{ }^{*} 1 A$; lane $4 * 1 A /{ }^{*} 1 A$; lane $5 * 2 A /{ }^{*} 2 A$; lane $6 * 1 A /{ }^{*} 1 A$; lane $7 * 1 A / * 4$; lane $8 * 4 A / * 41$; lane $9 * 1 A / * 41$; lane $10 * 2 A / * 41 ;$ lane $11 * 2 A / * 41$; lane $12 * 9 A / * 41$; lane 13 $\mathrm{H} 1 * 41$; lane $14 \mathrm{H} 9 * 41$ carrier. 


\section{Conclusions}

Pluripotent stem cells have a high self-renewal capability and can differentiate into any cell type in the body, making them an attractive tool for researchers in drug discovery and development. SCDHs offer a promising new tool for use in hepatic drug metabolism and toxicity screens, adding to available human derived cell models. There has been extensive research on SCDHs for this purpose, and while there is evidence SCDHs express drug-metabolizing enzymes, they remain in a de-differentiated state. This indicates there is a significant need for improvement on generating and characterizing SCDHs, particularly with regards to their metabolic capacity as it compares to primary hepatocytes. In this study, gene expression profiling and functional assays of CYP activity indicate SCDHs are largely immature hepatocytes, lacking significant CYP expression and activity. Based on gene expression profiling, SCDHs most closely resemble fetal hepatocytes, especially with regards to AFP, CYP3A7 and FMO1 expression. Functional assay of enzyme activity in SCDHs using a CYP cocktail revealed only minor CYP3A activity, below that observed in primary hepatocytes. These data demonstrates that more work needs to be done to promote the maturity of SCDHs. Enhanced expression and function of drug-metabolizing enzymes in SCDHs would make them a more viable option to supplant primary hepatocytes in the pharmaceutical industry for drug metabolism/liver toxicity assays. In addition, SCDHs may provide an improved in vitro system for evaluating genotype-phenotype relationships of the CYP enzymes and their impact on drug metabolism and toxicity. This is the first published report of genotyping in the WiCell ${ }^{\circledR}$ hESC lines with regards to ADME-relevant polymorphisms. In addition, we are able to demonstrate the CYPP2D6*41 splicing defect displays incomplete penetrance, with similar results observed in SCDHs and liver tissue. The pharmacogenetic data provided here is vital to understanding metabolism profiles when these hESC lines are used as a target tissue source for models of drug metabolism and toxicity.

\section{Acknowledgements}

The authors would like to thank the University of Washington (UW) Institute for Stem Cell and Regenerative Medicine, including Carol Ware, Christopher Cavanaugh, Jennifer Hesson and Savannah Cook for their input on culturing human embryonic stem cells. We would like to thank David Hay, Sebastian Greenhough and Dagmara Szkolnicka at the University of Edinburgh for teaching us their hepatocyte differentiation protocol and providing some samples. We would like to thank Sengkeo Srinouanprachanh, Jesse Tsai, Theo Bammler, Fred Farin, and Richard Beyer for assistance in running the Affymetrix DMET ${ }^{\mathrm{TM}}$ Plus Array. We would also like to thank James MacDonald for assistance in submitting the array data to the Gene Expression Omnibus. Support was provided for this work in part from the Drug Metabolism Transport and Pharmacogenetics Research Fund in the School of Pharmacy, University of Washington (to EJK); ES007033 (to EJK); Institute of Translational Health Sciences Ignition Award (to EJK); and T32GM007750 (to JLV). Research reported in this publication was supported by the National Center for Advancing Translational Sciences of the National Institutes of Health under award number TL1TR000422 (to JLV). The content is solely the responsibility of the authors and does not necessarily represent the official views of the National Institutes of Health.

\section{References}

[1] F.P. Guengerich, Human Cytochrome P450 Enzymes, in: P.R.O.d. Montellano (Ed.) Cytochrome P450: Structure, Mechanism, and Biochemistry, Kluwer Academic/Plenum Publishers, New York, 2005, pp. 377-530.

[2] H. Zhang, C.D. Davis, M.W. Sinz, A.D. Rodrigues, Expert Opin Drug Metab Toxicol 3 (2007) 667-687. 
[3] J.M. McKim, In Vitro Approaches for Determining Liver-Specific Toxicity of New Drug Candidates, in: A.G. Wilson (Ed.) New Horizons in Predictive Toxicology: Current Status and Application, The Royal Society of Chemistry, Cambridge, 2012, pp. 157-214.

[4] I. Johansson, M. Ingelman-Sundberg, Toxicological Sciences 120 (2010) 1-13.

[5] J.C. Davila, Toxicological Sciences 79 (2004) 214-223.

[6] Claire N. Medine, S. Greenhough, David C. Hay, Biochemical Society Transactions 38 (2010) 1033.

[7] P. Godoy, N.J. Hewitt, U. Albrecht, M.E. Andersen, N. Ansari, S. Bhattacharya, J.G. Bode, J. Bolleyn, C. Borner, J. Böttger, A. Braeuning, R.A. Budinsky, B. Burkhardt, N.R. Cameron, G. Camussi, C.-S. Cho, Y.-J. Choi, J. Craig Rowlands, U. Dahmen, G. Damm, O. Dirsch, M.T. Donato, J. Dong, S. Dooley, D. Drasdo, R. Eakins, K.S. Ferreira, V. Fonsato, J. Fraczek, R. Gebhardt, A. Gibson, M. Glanemann, C.E.P. Goldring, M.J. Gómez-Lechón, G.M.M. Groothuis, L. Gustavsson, C. Guyot, D. Hallifax, S. Hammad, A. Hayward, D. Häussinger, C. Hellerbrand, P. Hewitt, S. Hoehme, H.-G. Holzhütter, J.B. Houston, J. Hrach, K. Ito, H. Jaeschke, V. Keitel, J.M. Kelm, B. Kevin Park, C. Kordes, G.A. Kullak-Ublick, E.L. LeCluyse, P. Lu, J. Luebke-Wheeler, A. Lutz, D.J. Maltman, M. Matz-Soja, P. McMullen, I. Merfort, S. Messner, C. Meyer, J. Mwinyi, D.J. Naisbitt, A.K. Nussler, P. Olinga, F. Pampaloni, J. Pi, L. Pluta, S.A. Przyborski, A. Ramachandran, V. Rogiers, C. Rowe, C. Schelcher, K. Schmich, M. Schwarz, B. Singh, E.H.K. Stelzer, B. Stieger, R. Stöber, Y. Sugiyama, C. Tetta, W.E. Thasler, T. Vanhaecke, M. Vinken, T.S. Weiss, A. Widera, C.G. Woods, J.J. Xu, K.M. Yarborough, J.G. Hengstler, Archives of toxicology 87 (2013) 1315-1530.

[8] D. Szkolnicka, W. Zhou, B. Lucendo-Villarin, D.C. Hay, Annual Review of Pharmacology and Toxicology 53 (2013) 147-159.

[9] W.E. Evans, Science 286 (1999) 487-491.

[10] L.C. Wienkers, T.G. Heath, Nature Reviews Drug Discovery 4 (2005) 825-833.

[11] D.C. Hay, J. Fletcher, C. Payne, J.D. Terrace, R.C.J. Gallagher, J. Snoeys, J.R. Black, D. Wojtacha, K. Samuel, Z. Hannoun, A. Pryde, C. Filippi, I.S. Currie, S.J. Forbes, J.A. Ross, P.N. Newsome, J.P. Iredale, Proceedings of the National Academy of Sciences 105 (2008) 12301-12306.

[12] D. Szkolnicka, S.L. Farnworth, B. Lucendo-Villarin, D.C. Hay, Curr Protoc Stem Cell Biol 30 (2014) 1 G 5 1$1 \mathrm{G} 512$.

[13] M.F. Paine, M. Khalighi, J.M. Fisher, D.D. Shen, K.L. Kunze, C.L. Marsh, J.D. Perkins, K.E. Thummel, The Journal of pharmacology and experimental therapeutics 283 (1997) 1552-1562.

[14] L. Liu, G.M. Mugundu, B.J. Kirby, D. Samineni, P.B. Desai, J.D. Unadkat, Biopharmaceutics \& Drug Disposition 33 (2012) 207-217.

[15] G. Vogel, Science 287 (2000) 948-949.

[16] N.L. Magner, Y. Jung, J. Wu, J.A. Nolta, M.A. Zern, P. Zhou, Stem Cells 31 (2013) 2095-2103.

[17] E. Chiao, M. Elazar, Y. Xing, A. Xiong, M. Kmet, M.T. Millan, J.S. Glenn, W.H. Wong, J. Baker, Stem Cells 26 (2008) 2032-2041.

[18] J. Cai, Y. Zhao, Y. Liu, F. Ye, Z. Song, H. Qin, S. Meng, Y. Chen, R. Zhou, X. Song, Y. Guo, M. Ding, H. Deng, Hepatology 45 (2007) 1229-1239.

[19] H. Basma, A. Soto-Gutiérrez, G.R. Yannam, L. Liu, R. Ito, T. Yamamoto, E. Ellis, S.D. Carson, S. Sato, Y. Chen, D. Muirhead, N. Navarro-Álvarez, R.J. Wong, J. Roy-Chowdhury, J.L. Platt, D.F. Mercer, J.D. Miller, S.C. Strom, N. Kobayashi, I.J. Fox, Gastroenterology 136 (2009) 990-999.e994.

[20] S. Agarwal, K.L. Holton, R. Lanza, Stem Cells 26 (2008) 1117-1127.

[21] T.N. Bukong, T. Lo, G. Szabo, A. Dolganiuc, Liver International 32 (2012) 732-741.

[22] Y. Duan, X. Ma, W. Zou, C. Wang, I.S. Bahbahan, T.P. Ahuja, V. Tolstikov, M.A. Zern, Stem Cells 28 (2010) 674-686.

[23] M. Ghaedi, Y. Duan, M.A. Zern, A. Revzin, Journal of Tissue Engineering and Regenerative Medicine (2012) n/a-n/a.

[24] D.C. Hay, S. Pernagallo, J.J. Diaz-Mochon, C.N. Medine, S. Greenhough, Z. Hannoun, J. Schrader, J.R. Black, J. Fletcher, D. Dalgetty, A.I. Thompson, P.N. Newsome, S.J. Forbes, J.A. Ross, M. Bradley, J.P. Iredale, Stem Cell Research 6 (2011) 92-102. 
[25] J. Heo, E.-K. Ahn, H.-G. Jeong, Y.-H. Kim, S.-H. Leem, S.-J. Lee, E.-K. Park, M. Yang, Biochemical and Biophysical Research Communications 434 (2013) 235-240.

[26] S. Ogawa, J. Surapisitchat, C. Virtanen, M. Ogawa, M. Niapour, K.S. Sugamori, S. Wang, L. Tamblyn, C. Guillemette, E. Hoffmann, B. Zhao, S. Strom, R.R. Laposa, R.F. Tyndale, D.M. Grant, G. Keller, Development 140 (2013) 3285-3296.

[27] T.S. Ramasamy, J.S.L. Yu, C. Selden, H. Hodgson, W. Cui, Tissue Engineering Part A 19 (2013) 360-367.

[28] K. Takayama, M. Inamura, K. Kawabata, K. Katayama, M. Higuchi, K. Tashiro, A. Nonaka, F. Sakurai, T. Hayakawa, M. Kusuda Furue, H. Mizuguchi, Molecular Therapy 20 (2011) 127-137.

[29] K. Takayama, K. Kawabata, Y. Nagamoto, K. Kishimoto, K. Tashiro, F. Sakurai, M. Tachibana, K. Kanda, T. Hayakawa, M.K. Furue, H. Mizuguchi, Biomaterials 34 (2013) 1781-1789.

[30] T. Touboul, N.R.F. Hannan, S. Corbineau, A. Martinez, C. Martinet, S. Branchereau, S. Mainot, H. StrickMarchand, R. Pedersen, J. Di Santo, A. Weber, L. Vallier, Hepatology 51 (2010) 1754-1765.

[31] A. DeLaForest, M. Nagaoka, K. Si-Tayeb, F.K. Noto, G. Konopka, M.A. Battle, S.A. Duncan, Development 138 (2011) 4143-4153.

[32] D.C. Hay, D. Zhao, A. Ross, R. Mandalam, J. Lebkowski, W. Cui, Cloning and Stem Cells 9 (2007) 51-62.

[33] D.C. Hay, D. Zhao, J. Fletcher, Z.A. Hewitt, D. McLean, A. Urruticoechea-Uriguen, J.R. Black, C. Elcombe, J.A. Ross, R. Wolf, W. Cui, Stem Cells 26 (2008) 894-902.

[34] L. Rambhatla, C.P. Chiu, P. Kundu, Y. Peng, M.K. Carpenter, Cell Transplant 12 (2003) 1-11.

[35] D. Szkolnicka, S.L. Farnworth, B. Lucendo-Villarin, C. Storck, W. Zhou, J.P. Iredale, O. Flint, D.C. Hay, Stem Cells Transl Med 3 (2014) 141-148.

[36] A.B. McLean, K.A. D'Amour, K.L. Jones, M. Krishnamoorthy, M.J. Kulik, D.M. Reynolds, A.M. Sheppard, H. Liu, Y. Xu, E.E. Baetge, S. Dalton, Stem Cells 25 (2007) 29-38.

[37] P. Gripon, S. Rumin, S. Urban, J. Le Seyec, D. Glaise, I. Cannie, C. Guyomard, J. Lucas, C. Trepo, C. Guguen-Guillouzo, Proceedings of the National Academy of Sciences of the United States of America 99 (2002) 15655-15660.

[38] C. Aninat, A. Piton, D. Glaise, T. Le Charpentier, S. Langouet, F. Morel, C. Guguen-Guillouzo, A. Guillouzo, Drug metabolism and disposition: the biological fate of chemicals 34 (2006) 75-83.

[39] S.N. Hart, Y. Li, K. Nakamoto, E.A. Subileau, D. Steen, X.B. Zhong, Drug metabolism and disposition: the biological fate of chemicals 38 (2010) 988-994.

[40] H. Li, H. Wang, Expert Opin Drug Metab Toxicol 6 (2010) 409-426.

[41] A.H. Tolson, H. Wang, Adv Drug Deliv Rev 62 (2010) 1238-1249.

[42] R. Jover, R. Bort, M.J. Gomez-Lechon, J.V. Castell, Hepatology 33 (2001) 668-675.

[43] C.E. Fluck, P.E. Mullis, A.V. Pandey, Biochem Biophys Res Commun 401 (2010) 149-153.

[44] A.V. Pandey, C.E. Fluck, Pharmacology \& therapeutics 138 (2013) 229-254.

[45] S. Langton, L.J. Gudas, Dev Biol 315 (2008) 331-354.

[46] L.J. Gudas, J.A. Wagner, J Cell Physiol 226 (2011) 322-330.

[47] S. Lutsenko, R.G. Efremov, R. Tsivkovskii, J.M. Walker, J Bioenerg Biomembr 34 (2002) 351-362.

[48] M. Ingelman-Sundberg, S.C. Sim, A. Gomez, C. Rodriguez-Antona, Pharmacology \& Therapeutics 116 (2007) 496-526.

[49] H. Smith, Eaton, DL, Bammler, TK, Polymorphisms in Xenobiotic Conjugation, in: L. Costa, Eaton, DL (Ed.) Gene-Environment Interactions: The Fundamentals of Ecogenetics, Wiley Press, New York, 2006, pp. 127-158.

[50] J.M. Hoskins, R.M. Goldberg, P. Qu, J.G. Ibrahim, H.L. McLeod, JNCI Journal of the National Cancer Institute 99 (2007) 1290-1295.

[51] Y. Duan, A. Catana, Y. Meng, N. Yamamoto, S. He, S. Gupta, S.S. Gambhir, M.A. Zern, Stem Cells 25 (2007) 3058-3068.

[52] M. Ek, T. Söderdahl, B. Küppers-Munther, J. Edsbagge, T.B. Andersson, P. Björquist, I. Cotgreave, B. Jernström, M. Ingelman-Sundberg, I. Johansson, Biochemical Pharmacology 74 (2007) 496-503. 
[53] R. Ghotbi, M. Christensen, H.-K. Roh, M. Ingelman-Sundberg, E. Aklillu, L. Bertilsson, European Journal of Clinical Pharmacology 63 (2007) 537-546.

[54] S. Raimundo, Clinical Pharmacology \& Therapeutics 76 (2004) 128-138.

[55] C. Toscano, K. Klein, J. Blievernicht, E. Schaeffeler, T. Saussele, S. Raimundo, M. Eichelbaum, M. Schwab, U.M. Zanger, Pharmacogenet Genomics 16 (2006) 755-766.

[56] T. Rau, S. Diepenbruck, I. Diepenbruck, T. Eschenhagen, Clin Pharmacol Ther 80 (2006) 555-558; author reply 558-560.

(C)2016 by the authors; licensee IAPC, Zagreb, Croatia. This article is an open-access article distributed under the terms and conditions of the Creative Commons Attribution license (http://creativecommons.org/licenses/by/3.0/) (cc) EY 


\section{Supplemental material}

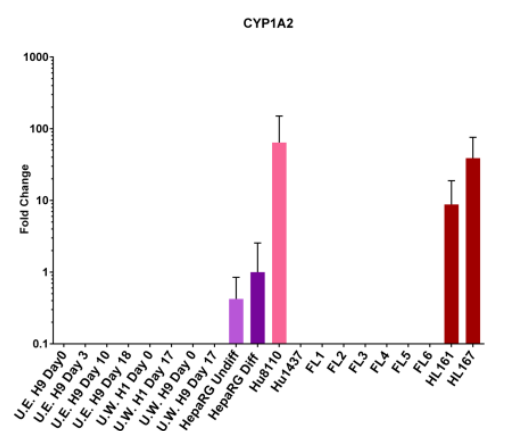

CYP2B6

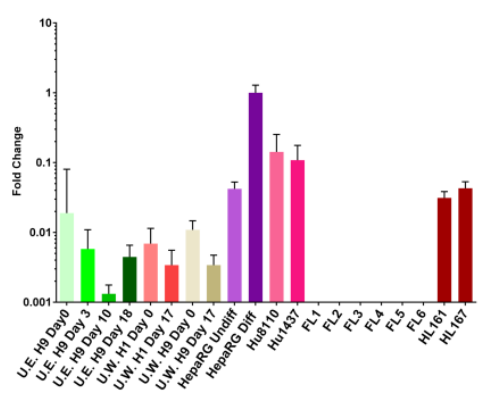

CYP2C19

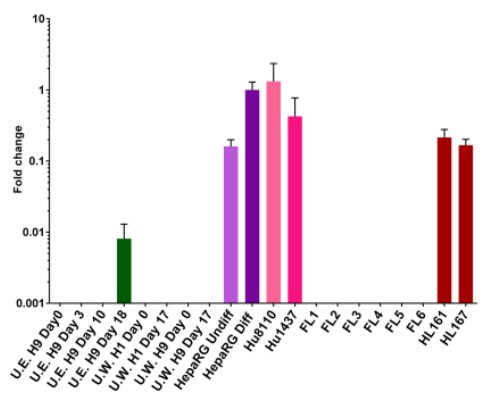

FMO3

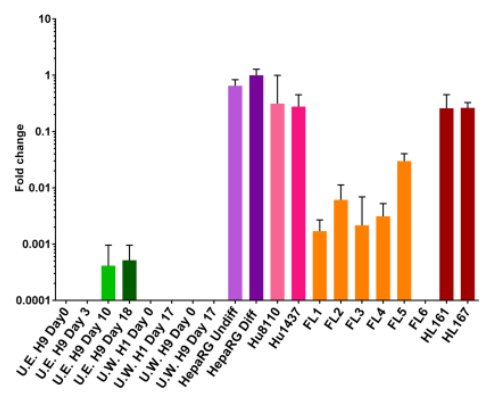

UGT2B4

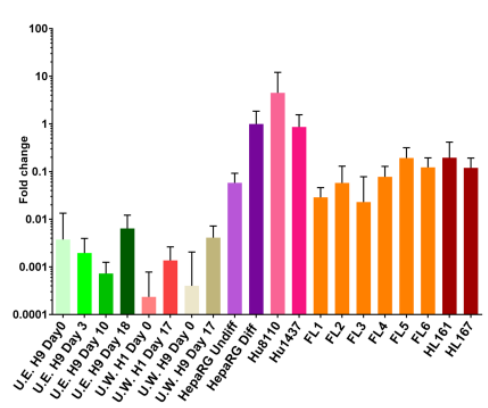

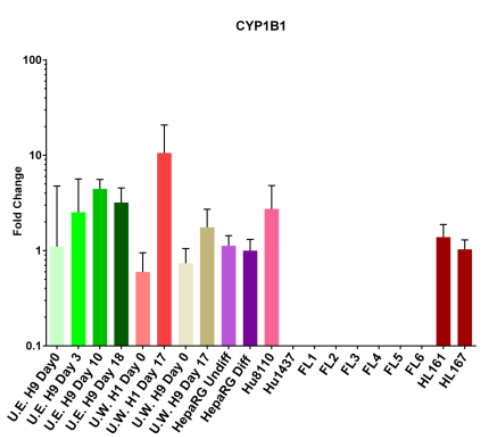

CYP2C8

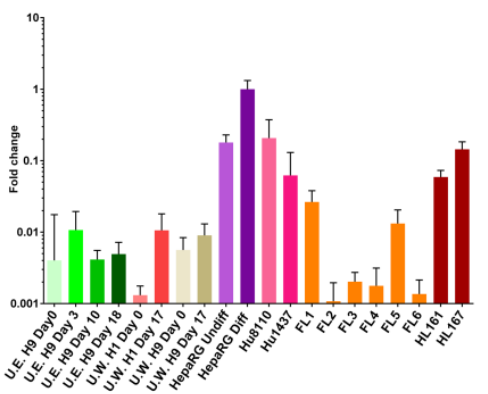

CYP2D6

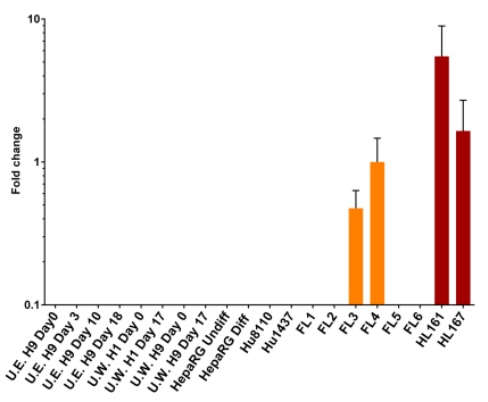

UGT1A1

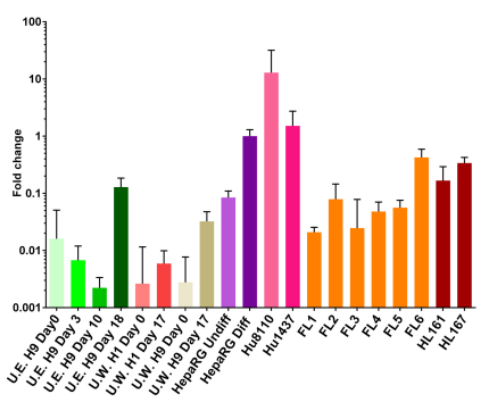

GSTM1

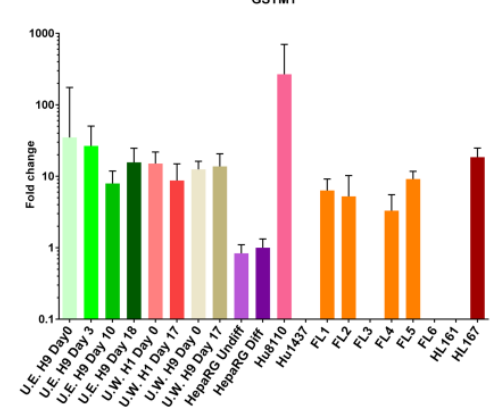

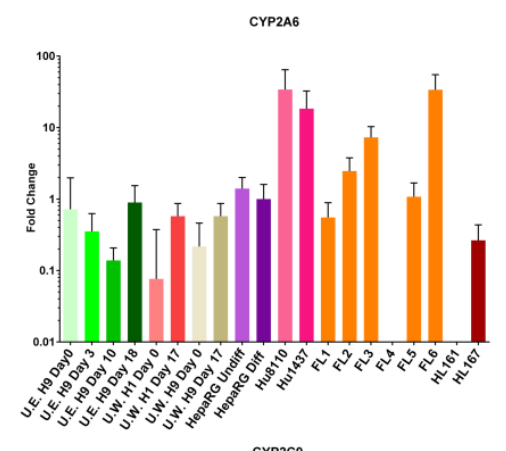

CYP2C9

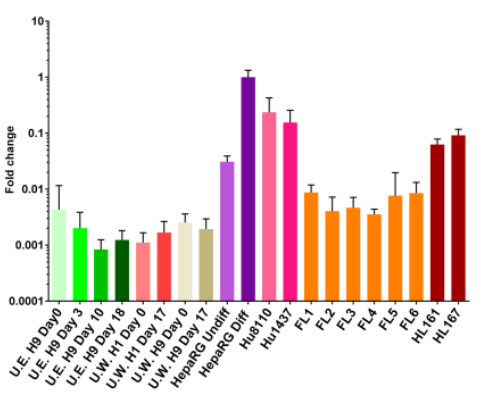

CYP2E1

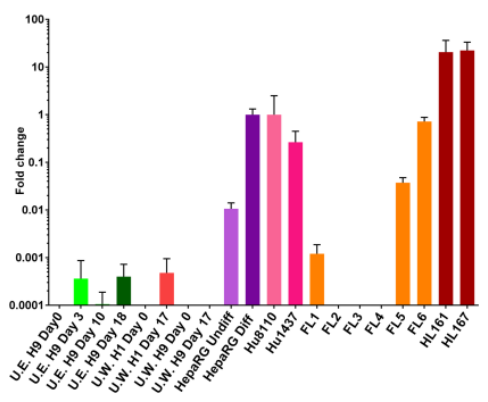

UGT1AG

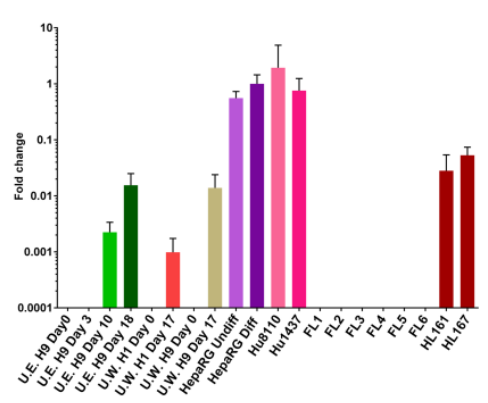

GSTP1

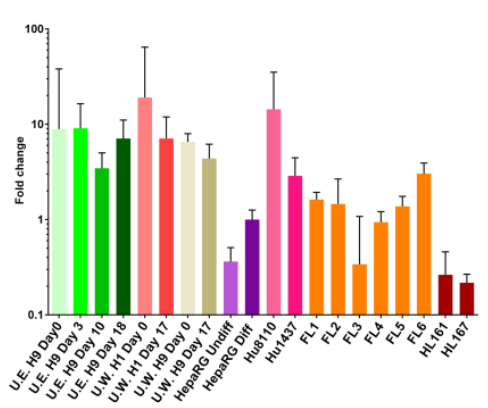



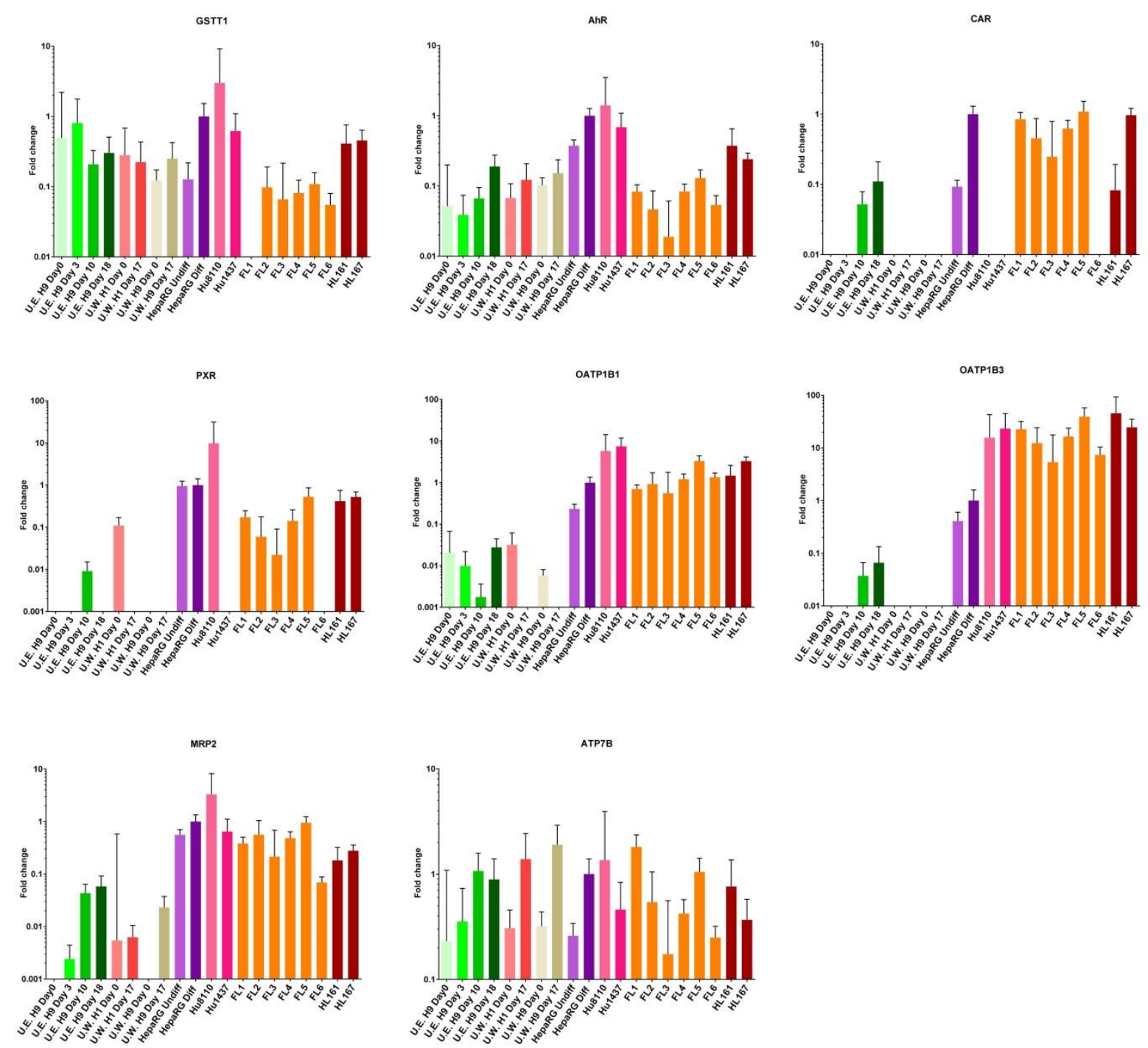

Supplemental Figure 1. SCDH gene expression characterization. Additional qRT-PCR results shown as fold change compared to differentiated HepaRG cells, which was set to 1. GUS-B was used as a housekeeping gene. For all stem cell and SCDH samples, error bars represent a pool of triplicate biological replicates and triplicate technical replicates. For all other samples, error bars represent triplicate technical replicates. HepaRG Undiff represents undifferentiated HepaRG cells; HepaRG Diff represents differentiated HepaRG cells; FL1, FL2, FL3, FL4, FL5, FL6 represent fetal liver tissue 1, 2, 3, 4, 5, 6, respectively; HL161 and HL167 represent human liver bank samples 161 and 167 , respectively. 